University of Nebraska - Lincoln DigitalCommons@University of Nebraska - Lincoln

USGS Staff -- Published Research

US Geological Survey

2005

\title{
New data for Late Pleistocene Pinedale alpine glaciation from southwestern Colorado
}

Larry Benson

US Geological Survey, great.basin666@gmail.com

Richard Madole

US Geological Survey

Gary Landis

US Geological Survey

John Gosse

Dalhousie University

Follow this and additional works at: http://digitalcommons.unl.edu/usgsstaffpub

Benson, Larry; Madole, Richard; Landis, Gary; and Gosse, John, "New data for Late Pleistocene Pinedale alpine glaciation from southwestern Colorado" (2005). USGS Staff-- Published Research. 757.

http:// digitalcommons.unl.edu/usgsstaffpub/757

This Article is brought to you for free and open access by the US Geological Survey at DigitalCommons@University of Nebraska - Lincoln. It has been accepted for inclusion in USGS Staff -- Published Research by an authorized administrator of DigitalCommons@University of Nebraska - Lincoln. 


\title{
New data for Late Pleistocene Pinedale alpine glaciation from southwestern Colorado
}

\author{
Larry Benson $^{\mathrm{a}, *}$, Richard Madole ${ }^{\mathrm{b}}$, Gary Landis ${ }^{\mathrm{c}}$, John Gosse $^{\mathrm{d}}$ \\ ${ }^{\mathrm{a}}$ US Geological Survey, 3215 Marine Street, Boulder, CO 80303-1066, USA \\ ${ }^{\mathrm{b}}$ US Geological Survey, MS 980, Denver Federal Center, Lakewood, CO 80225, USA \\ ${ }^{\mathrm{c}}$ US Geological Survey, MS 963, Denver Federal Center, Lakewood, CO 80225, USA \\ ${ }^{\mathrm{d}}$ Earth Sciences, Dalhousie University, 4616 LSC, Edsell Castle Circle, Halifax, Nova Scotia, Canada B3H $3 J 5$
}

Received 6 February 2004; accepted 8 July 2004

\begin{abstract}
New cosmogenic surface-exposure ages of moraine-crest boulders from southwestern Colorado are compared with published surface-exposure ages of boulders from moraine complexes in north-central Colorado and in west-central (Fremont Lake basin) Wyoming. ${ }^{10} \mathrm{Be}$ data sets from the three areas were scaled to a single ${ }^{10} \mathrm{Be}$ production rate of $5.4 \mathrm{at} / \mathrm{g} / \mathrm{yr}$ at sea level and high latitude (SLHL), which represents the average ${ }^{10} \mathrm{Be}$ production rate for two high-altitude, mid-latitude sites in the western United States (US) and Austria. Multiple nuclide ages on single boulders indicate that this ${ }^{10} \mathrm{Be}$ production rate yields ages comparable to those calculated with a commonly used ${ }^{36} \mathrm{Cl}$ production scheme. The average age and age range of moraine-crest boulders on terminal moraines at the southwestern Colorado and Wyoming sites are similar, indicating a retreat from their positions $\sim 16.8{ }^{36} \mathrm{Cl} \mathrm{ka}$ (Cosmogenic ages in this paper are labeled ${ }^{10} \mathrm{Be}$ or ${ }^{36} \mathrm{Cl}$ ka or just ka when both ${ }^{10} \mathrm{Be}$ or ${ }^{36} \mathrm{Cl}$ ages are being discussed; radiocarbon ages are labeled ${ }^{14} \mathrm{C} \mathrm{ka}$, calibrated radiocarbon are labeled cal $\mathrm{ka}$, and calendar ages are labeled calendar ka. Errors $( \pm 1 \sigma)$ associated with ages are shown in tables. Radiocarbon ages were calibrated using the data of Hughen et al. (Science 303 (2004) 202). This suggests a near-synchronous retreat of Pinedale glaciers across a 470-km latitudinal range in the Middle and Southern Rocky Mountains. Hypothetical corrections for snow shielding and rock-surface erosion shifts the time of retreat to between 17.2 and 17.5 ${ }^{10} \mathrm{Be} \mathrm{ka}$ at Pinedale, Wyoming, and between 16.3 and $17.3{ }^{36} \mathrm{Cl}$ ka at Hogback Mountain, Colorado.

(C) 2004 Elsevier Ltd. All rights reserved.
\end{abstract}

\section{Introduction}

Temperate alpine glaciers respond rapidly to climate change on both regional and global scales. In terms of climate forcing, fluctuations in the sizes of existing western North American glaciers have been shown to be associated with changes in atmospheric circulation over the North Pacific Ocean and western North America. In particular, fluctuations in the size of modern glaciers have been correlated with changes in the Southern Oscillation Index and Northern Hemisphere air temperature

\footnotetext{
*Corresponding author. Tel.:+1-303-541-3005; fax: +1-303-4472505.

E-mail address: 1benson@usgs.gov (L. Benson).
}

(McCabe et al., 2000). Thus, knowledge of the timing of past glacier fluctuations may aid in understanding past changes in atmospheric circulation and climate.

The relation of western North American alpine glaciers to climate forcing during marine-isotope stages 3 (MIS3, 59-24 calendar ka) and 2 (MIS2, 24-11.7 calendar ka) has yet to be explained adequately in terms of detailed changes in atmospheric circulation. Instead, fluctuations of western alpine glaciers have often been correlated with North Atlantic air-temperature excursions, such as those associated with Heinrich $(\mathrm{H})$ events (Clark and Bartlein, 1995; Phillips et al., 1996a; Licciardi et al., 2004) and Dansgaard-Oeschger (D-O) events (Benson et al., 2003), under the assumption that these events are hemispheric or global in scale. 
Climate forcing of glacier advances and retreats also has been attributed to the waxing and waning of the Laurentide Ice sheet (LIS) and the repositioning of the polar jet stream (PJS), which responds to changes in size of the LIS. Using a $5.1 \mathrm{at} / \mathrm{g} / \mathrm{yr}$ production rate for ${ }^{10} \mathrm{Be}$ at SLHL, Licciardi et al. (2004) have suggested that alpine glaciers in the "northern" (north of $\sim 45.5^{\circ} \mathrm{N}$ ) region of the western US reached their maximum extent prior to the last glacial maximum (LGM at $22 \pm 2$ calendar ka) and, during the LGM "experienced subdued advances or retreated in response to their proximity to the LIS." They concluded that the glacial records they examined demonstrated substantial differences in the responses of western US glaciers to climate forcing associated with the LGM. They also stated that glacial retreat occurred at $21-20{ }^{10} \mathrm{Be}$ ka in the "southern" (south of $\sim 45.5^{\circ} \mathrm{N}$ ) region of the western US, and that widespread deglaciation of the western US occurred at $\sim 17{ }^{10} \mathrm{Be} \mathrm{ka}$, and was part of a world-wide deglaciation associated with the warming following Heinrich event 1 (H-1).

In this paper, we present new surface-exposure ages of Pinedale terminal moraines in southwestern Colorado and discuss them in context with previously published surface-exposure ages for Pinedale terminal moraines in north-central Colorado (Benson et al., 2004) and with recalculated surface-exposure ages of Pinedale moraines in west-central Wyoming (Gosse et al., 1995, 2003). With knowledge of the sources of error inherent in surface-exposure ages, we compare and contrast methods used by various authors for determining moraine ages and discuss the difficulties in extracting objective information on the initiation, duration, and termination of moraine formation.

\section{Study areas}

Fig. 1 shows the locations of the six localities where the moraine-crest boulder surface-exposure ages discussed in this study were obtained. Figs. 2 and 3 show the sample site locations and surficial geology of the Colorado study areas, and Fig. 4 shows the sample sites and geology of the Fremont Lake area, which is just northeast of Pinedale, Wyoming (Gosse et al., 1995, 2003). Sample site elevations, boulder heights and locations, and the thickness of all samples from the Colorado and Wyoming study areas are given in Appendix A.

The Fremont Lake basin contains the glacial deposits for which Blackwelder (1915) proposed the names Pinedale drift and Pinedale stage. Subsequently, these deposits became the type Pinedale Till (Richmond, 1964,

\footnotetext{
${ }^{1}$ The latitude that separates their northern and southern sites is based on the location of the Yellowstone site
}

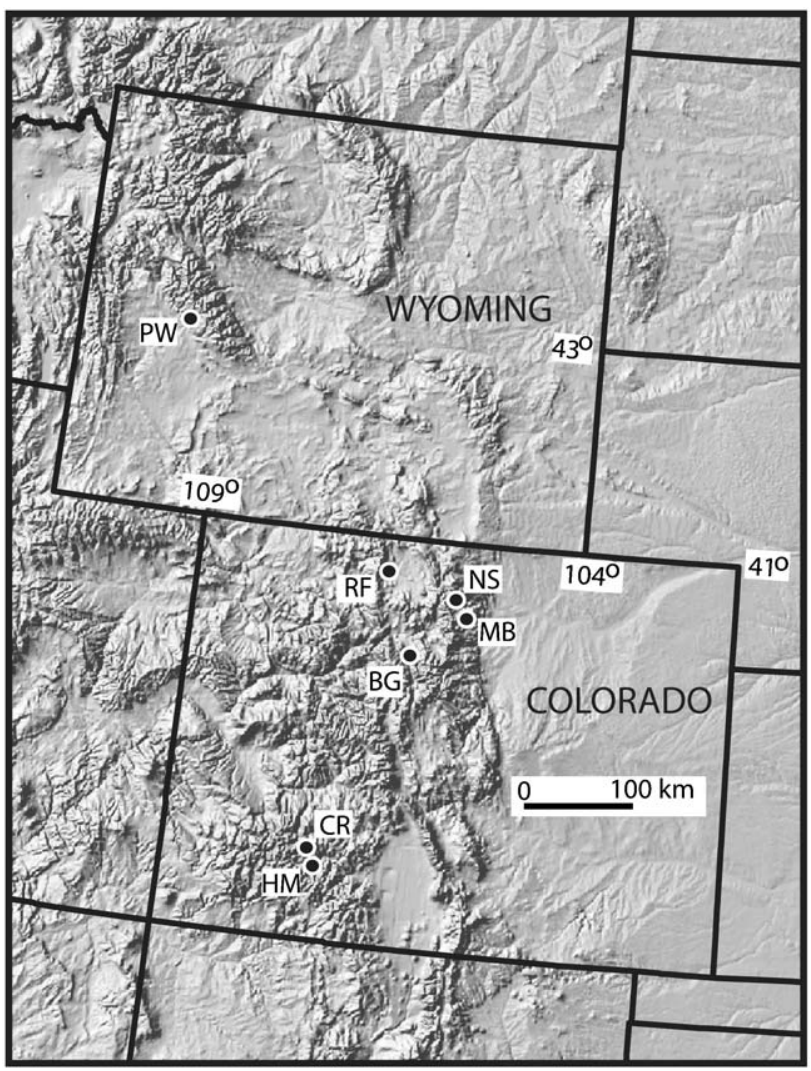

Fig. 1. Location map of Pinedale (PW), Roaring Fork (RF), North St. Vrain (NS), Middle Boulder Creek (MB), Continental Reservoir (CR), Hogback Mountain (HM), and Butler Gulch (BG) sites.

1987), and the term Pinedale eventually was adopted throughout much of the Rocky Mountain region for both the time and the deposits of the last extensive glaciation. The Pinedale glacier descended from an ice cap that mantled the Wind River Range, the summit of which is $\sim 45 \mathrm{~km}$ east of the Pinedale limit near the southwest end of Fremont Lake (Table 1).

Much effort has been expended on determining the chronology of the Pinedale glaciation. The ages of the type-Pinedale moraines are especially important. Therefore, Gosse et al. $(1995,2003)$ used ${ }^{10} \mathrm{Be}$ to obtain surface-exposure ages of boulders on Pinedale terminal and recessional moraines in the Fremont Lake area (Fig. 4). The ages of boulders from the Fremont Lake lobe, calculated using a production rate of $5.4 \mathrm{at} / \mathrm{g} / \mathrm{yr}$ at SLHL, range from 22.9 to $16.7{ }^{10} \mathrm{Be} \mathrm{ka}$, and one boulder yielded an anomalous young date of $15.1{ }^{10} \mathrm{Be} \mathrm{ka}$. The latter boulder came from the back of the moraine, not its crest, and its anomalous age may reflect sediment mobilization above melting buried ice (Gosse et al., 2003). From these ages, it can be argued that the Pinedale glacier initially reached its maximum extent $\sim 22.9{ }^{10} \mathrm{Be} \mathrm{ka}$ and began to recede $\sim 16.7{ }^{10} \mathrm{Be} \mathrm{ka}$. Gosse et al. (1995) ruled out differential erosion of boulder 


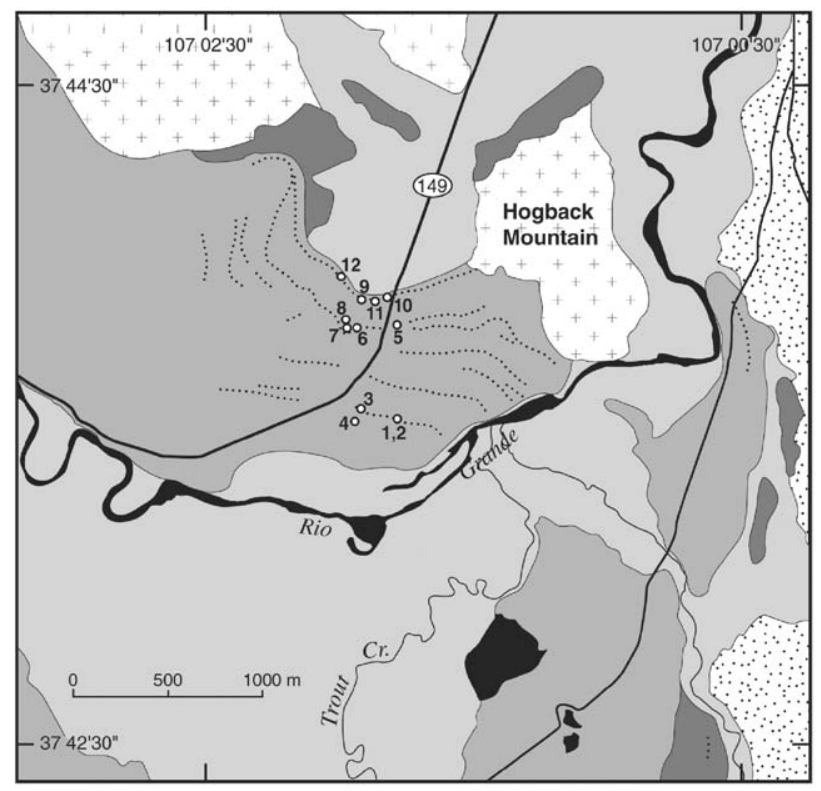

(A)
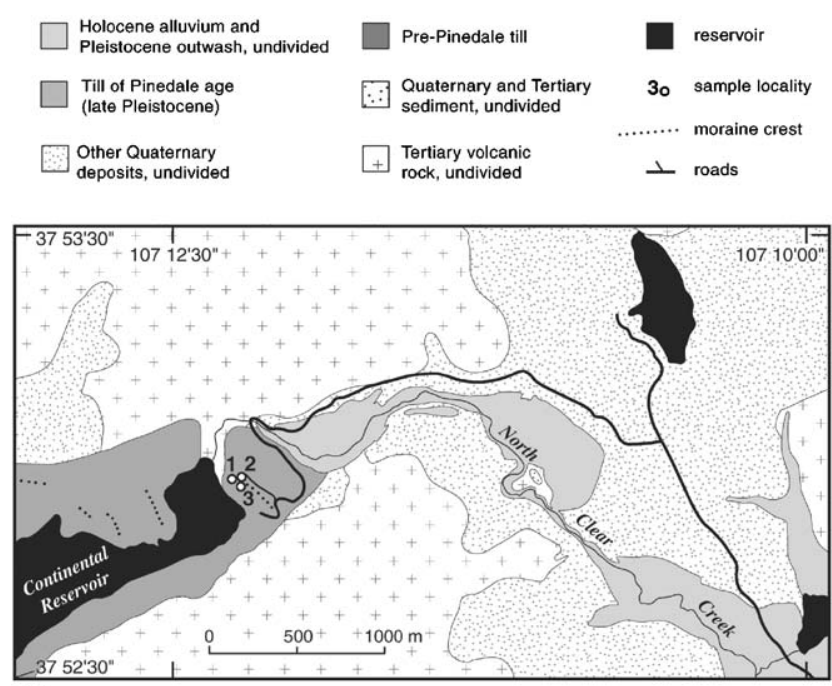

(B)

Fig. 2. Surficial geologic maps of (A) the Hogback Mountain site, and (B) the Continental Reservoir site (see Fig. 1 for locations).

surfaces as a factor contributing to the age range of boulders because the presence of glacial polish on some boulder surfaces suggested that $<2 \mathrm{~mm}$ of erosion had occurred since the boulders were deposited. Zimmerman et al. (1994), in a study of fire-induced spallation of Pinedale moraines, also demonstrated that the mean rate of boulder erosion on these moraines was $<1 \mathrm{~mm} /$ yr. The heights of the boulders (1.7-5.5 m, Appendix A) make it unlikely that either snow or sediment shielding affected their surface-exposure ages. It is also unlikely that the moraine-crest boulders rotated after their deposition because the boulders are from stable parts of the moraine which had not subsided during the melting of buried ice.
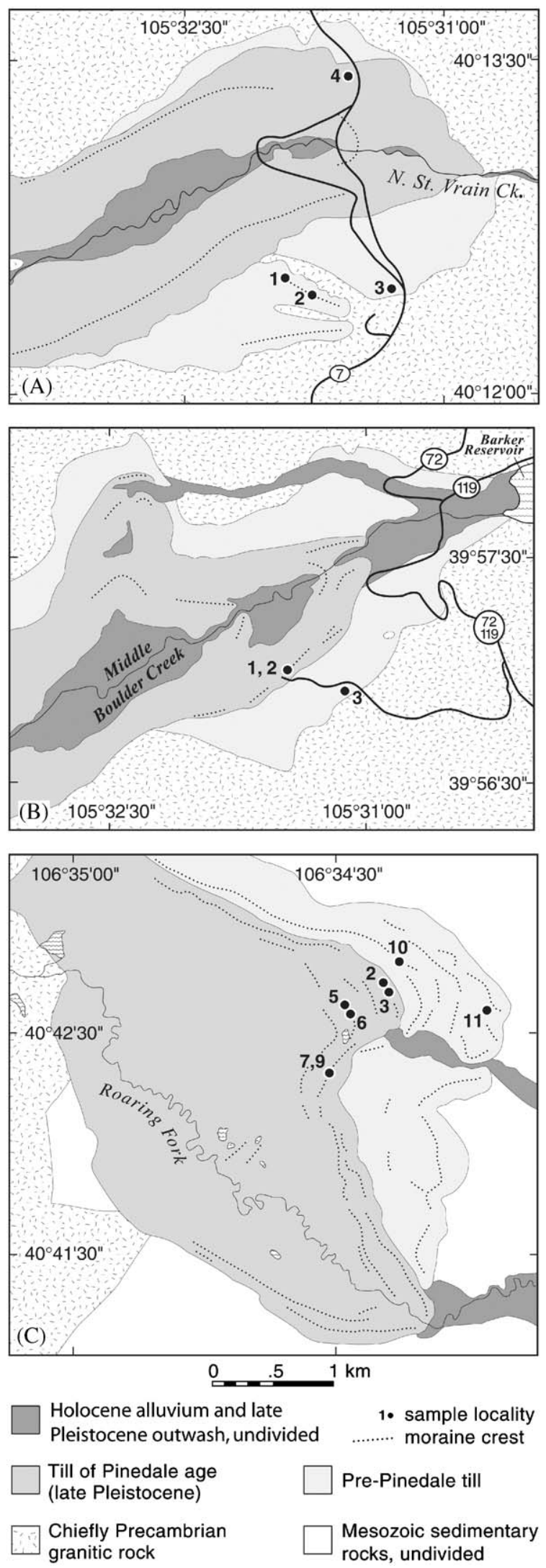

Fig. 3. Surficial geologic maps of (A) the North St. Vrain site, (B) the Middle Boulder Creek site, and (C) the Roaring Fork site (see Fig. 1 for locations) (after Benson et al., 2004). 


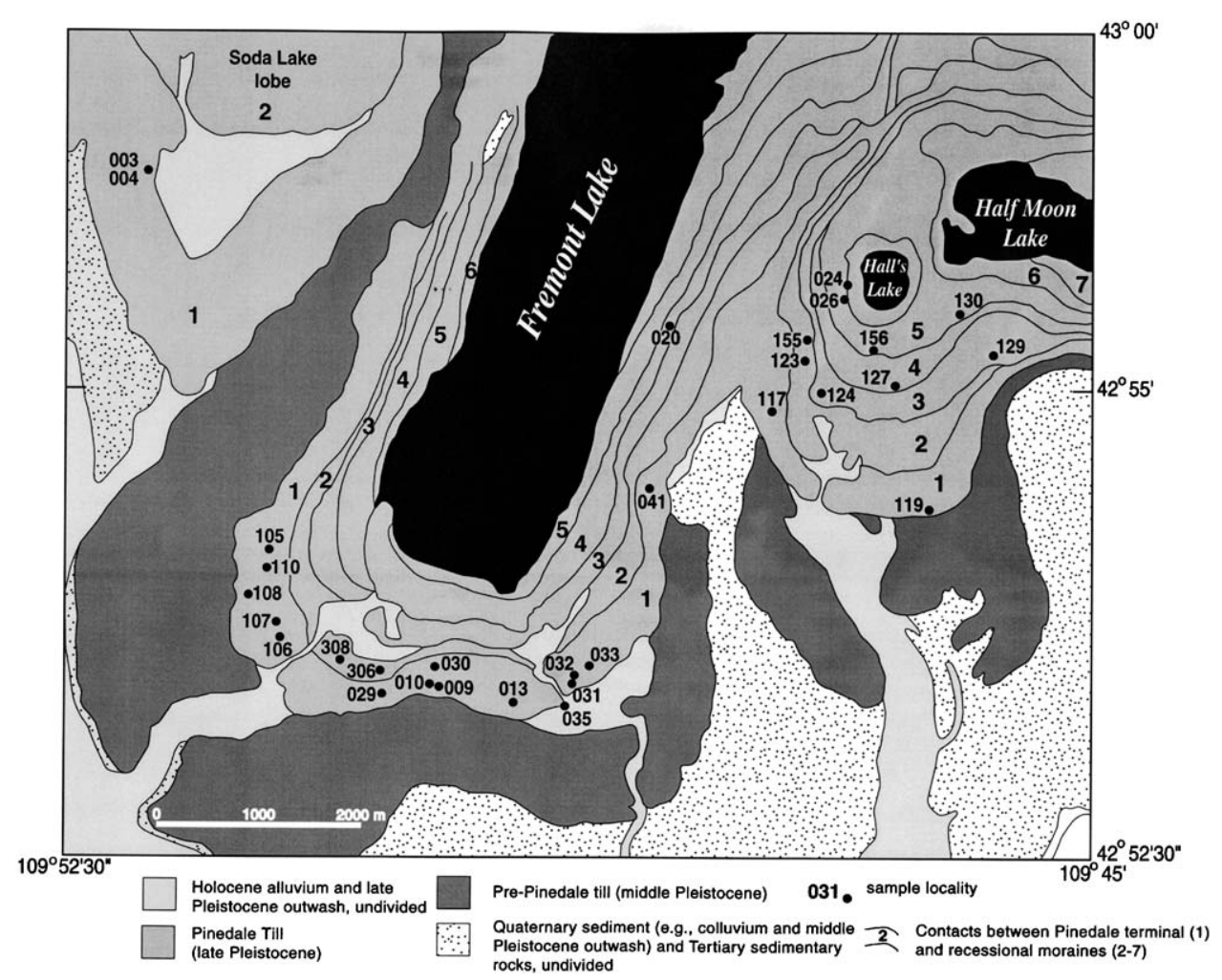

Fig. 4. Surficial geologic map of the Pinedale site in west-central Wyoming (after Richmond $(1973,1987)$ and Gosse et al. (1995). Three glacial lobes were named Soda Lake, Fremont Lake, and Half Moon Lake.

Table 1

Lengths of principal glaciers at sites in Colorado and Wyoming. Moraine locations given in bold

\begin{tabular}{ll}
\hline Glacier & $\begin{array}{l}\text { Maximum length } \\
(\mathrm{km})\end{array}$ \\
\hline $\begin{array}{l}\text { North St. Vrain Creek } \\
\text { Middle Boulder Creek }\end{array}$ & 16 \\
$\quad$ South Fork & 16 \\
$\quad$ North Fork & 19 \\
Roaring Fork & 12 \\
$\quad$ Main stem & 15 \\
$\quad$ Red Canyon to Roaring Fork & \\
Continental Reservoir & 24 \\
$\quad$ Lost Trail Creek to North Clear Creek & \\
Hogback Mountain & 56 \\
$\quad$ Main stem Rio Grande River & 60 \\
$\quad$ Pole Creek to Rio Grande River & 58 \\
$\quad$ Bear Creek to Rio Grande River & \\
Fremont Lake & 45 \\
$\quad$ Mammoth Glacier to Wells Creek to Pine & \\
Creek & \\
\hline
\end{tabular}

Recently, Benson et al. (2004) used ${ }^{36} \mathrm{Cl}$ to determine the surface-exposure ages of eight boulders on Pinedale terminal moraines at three localities in north-central Colorado, 360-460 km southeast of the Fremont Lake area (Fig. 3). The north-central Colorado glaciers were much smaller than the Fremont Lake glacier; i.e., there, end moraines are only $12-19 \mathrm{~km}$ downvalley from their ice divides. The ages of boulders on the Colorado moraines ranged from 20.9 to $16.5{ }^{36} \mathrm{Cl} \mathrm{ka}$ (assuming no corrections for rock erosion or snow shielding). The ${ }^{10} \mathrm{Be}$ ages of three Pinedale boulders, calculated using a production rate of $5.37 \pm 0.22 \mathrm{at} / \mathrm{g} / \mathrm{yr}$ at SLHL agreed closely $(\leqslant 5 \%)$ with the ${ }^{36} \mathrm{Cl}$ ages of the same boulders.

In this paper, we first compare surface-exposure ages in three widely separated regions: (1) the type area of the Pinedale Till (Fig. 4), (2) localities in the Front Range and Park Range of north-central Colorado (Fig. 3), and (3) two localities in the San Juan Mountains of southwestern Colorado (Fig. 2). The surface-exposure ages from the two localities in the San Juan Mountains are previously undescribed. Both localities are in the Rio Grande drainage basin. One locality, referred to as Hogback Mountain, marks the maximum extent of the main-stem Rio Grande glacier, some $60 \mathrm{~km}$ from the ice divide that existed at the head of the valley during Pinedale time. The other area, referred to as Continental Reservoir, is in the North Clear Creek drainage basin. The moraine at Continental Reservoir is located $45 \mathrm{~km}$ downvalley from the ice divide.

During the late Pleistocene, a large ice field mantled much of the central San Juan Mountains. Flow within the ice field was complex, but ultimately funneled into 12 valley glaciers that radiated in all directions except west (Atwood and Mather, 1932). Ice that drained eastward 
into the upper Rio Grande and its valley-head tributaries formed the second largest late-Pleistocene valley glacier in the San Juan Mountains (the southflowing Animas River glacier was the largest). The Rio Grande glacier was as much as $60 \mathrm{~km}$ long from ice divide to its maximum limit and, according to Atwood and Mather (1932), covered nearly $1000 \mathrm{~km}^{2}$. These authors also determined that a complex of 56 catchments in the upper part of the basin contributed ice to the Rio Grande glacier. The ice-flow pattern remained complex even through the midsection of the glacier where ice split into at least six parallel streams around and through high, narrow mesas (the Finger Mesas) before recombining into a single ice body about $14 \mathrm{~km}$ upvalley from the glacier terminus at Hogback Mountain (Fig. 2A). At its maximum extent, the main-stem Rio Grande glacier met the terminus of a smaller northflowing valley glacier that drained several cirques through five valleys that converged to form what Atwood and Mather (1932) termed the Red Mountain glacier. The length of this glacier was about $18 \mathrm{~km}$. Present-day Trout Creek (Fig. 2A) drains the area formerly occupied by the Red Mountain glacier.

In spite of the vast area covered by glaciers in the San Juan Mountains, numerical ages for the retreat of Pinedale glaciers is available from only one locality, not including those reported in this paper. The locality is in the upper valley of the Animas River (Carrara et al., 1984; Elias et al., 1991). Carrara et al. (1984) and Elias et al. (1991) obtained several ${ }^{14} \mathrm{C}$ ages that indicated recession of the largest Pinedale valley glacier in Colorado was complete prior to $10.0{ }^{14} \mathrm{C} \mathrm{ka}$ $(11.3 \mathrm{cal} \mathrm{ka}){ }^{2}$ Radiocarbon ages of wood and moss from a depth of $1.75 \mathrm{~m}$ in the Lake Emma core indicate that the moss is $3.5{ }^{14} \mathrm{C}$ ka older than the wood. This implies that the carbon in the moss had a $3.5{ }^{14} \mathrm{C} \mathrm{ka}$ reservoir effect (the water in which the moss grew had not equilibrated with the ${ }^{14} \mathrm{C}$ of the atmosphere, and, therefore, acquired an "old" ${ }^{14} \mathrm{C}$ date when it formed). Assuming that the reservoir effect was the same when the lake began to form, the age of moss $(14.94 \pm 0.25$ ${ }^{14} \mathrm{C} \mathrm{ka}$ ) from organic-rich lake sediment that overlies sandy till at the base of the core indicates that the Pinedale glacier was gone from this locality before 11.1 ${ }^{14} \mathrm{Cka}$ (13.1 cal ka).

\section{Methods}

\subsection{Sample collection}

All samples from the Hogback Mountain locality were collected on the north side of the Rio Grande River

\footnotetext{
${ }^{2}$ All radiocarbon ages in this paper have been calibrated using the data of Hughen et al. (2004).
}

from boulders on moraines formed by the main body of the Rio Grande glacier. Samples from the Colorado sites were collected with hammer and chisel from the tops of boulders on or near moraine crests. The latitude, longitude, and elevation of each boulder was estimated using a hand-held GPS unit. The elevation estimate was further refined using sample locations plotted on topographic maps; the estimated horizontal accuracy was $3-8 \mathrm{~m}$ and the estimated vertical accuracy was better than $10 \mathrm{~m}$. The north-central Colorado boulders are Middle Proterozoic granite and quartz monzonite that range in height from 50 to $160 \mathrm{~cm}$. The southwestern Colorado boulders are welded tuffs with the exception of sample HM-1, which is a basalt. The tops of these boulders project $30-300 \mathrm{~cm}$ above the ground surface. Although the Colorado boulders are not as tall as the Wyoming boulders $(170-550 \mathrm{~cm})$, the possibility of their exhumation is not great. In general, they were taken from moraine-crest positions that give little or no indication of sediment removal, and the boulders from southwestern Colorado came from low-relief broadcrested moraines that have minimal potential for soil erosion.

\section{2. ${ }^{36} \mathrm{Cl}$ and ${ }^{10}$ Be determinations}

Laboratory and numerical procedures for ${ }^{36} \mathrm{Cl}$ and ${ }^{10} \mathrm{Be}$ age determinations are the same as those in Benson et al. (2004) and are discussed in Appendix B. The chemical data and isotopic ratios of $\mathrm{Cl}$ used in the calculation of surface-exposure ages for southwestern Colorado moraine-crest boulders also are given in Appendix B. Chemical data used in the calculation of north-central Colorado moraine-crest boulders are tabulated in Benson et al. (2004). The isotopic ratios of $\mathrm{Cl}$ used in the calculation of surface-exposure ages for north-central Colorado boulders are given in Appendix $\mathrm{B}$ and the data necessary for calculation of ${ }^{10} \mathrm{Be}$ ages of west-central Wyoming (Pinedale) moraine-crest boulders are given in Gosse et al. (1995, 2003).

To compare ${ }^{36} \mathrm{Cl}$ surface-exposure ages of Colorado boulders with ${ }^{10} \mathrm{Be}$ surface-exposure ages of Wyoming boulders, it was necessary to select cosmogenic production values for the two nuclides that resulted in comparable ages. To accomplish this, we compared ${ }^{36} \mathrm{Cl}$ and ${ }^{10} \mathrm{Be}$ surface-exposure ages of three northcentral Colorado boulders using an average ${ }^{10} \mathrm{Be}$ production value of $5.4 \mathrm{at} / \mathrm{g} / \mathrm{yr}$ obtained from two mid-latitude, high-elevation sites in Wyoming $(5.37 \pm 0.22 \mathrm{at} / \mathrm{g} / \mathrm{yr}$, Klein and Gosse, 2002) and Austria $(5.44 \pm 0.19 \mathrm{at} / \mathrm{g} / \mathrm{yr}, \mathrm{Kubik}$ and Ivy-Ochs, 2004) and an average ${ }^{10} \mathrm{Be}$ production value $(5.1 \mathrm{at} / \mathrm{g} / \mathrm{yr})$ fit to several sites that varied in altitude and latitude (Stone, 2000). The two ${ }^{10} \mathrm{Be}$ production rates differ mainly because one (Stone, 2000) uses a somewhat smaller muon contribution $(2.2 \%$ vs. $3.6 \%)$ to the total production, and the 
other (Kubik and Ivy-Ochs, 2004) scales the two muon components (negative and fast) differently with altitude. Boulder ages also were calculated using ${ }^{36} \mathrm{Cl}$ production values from Stone et al. (1996) and Evans et al. (1997) and from Phillips et al. (1996b, 2001) and Evans et al. (1998). Use of the ${ }^{36} \mathrm{Cl}$ production values of Phillips et al. (1996b, 2001) and Evans et al. (1998), and the ${ }^{10} \mathrm{Be}$ production value obtained by averaging the values of Klein and Gosse (2002) and Kubik and Ivy-Ochs (2004) resulted in comparable ${ }^{10} \mathrm{Be}$ and ${ }^{36} \mathrm{Cl}$ ages on individual boulders (Table 2, column 4). In this paper, all referenced ${ }^{10} \mathrm{Be}$ surface-exposure ages have been rescaled using a production rate of $5.4 \mathrm{at} / \mathrm{g} / \mathrm{yr}$ at SLHL.

\subsection{Topographic (distant) and snow shielding}

The Continental Reservoir site in southwestern Colorado (Fig. 2) is the only site discussed in this paper that is topographically shielded. Shielding at this site was evaluated by means of a topographic map. The inclination and horizontal distance between the sample site and nearby summits were measured along radii spaced $30^{\circ}$ apart. A topographic shielding value of 0.997 was calculated from the measurements using the following equation (Dunne et al., 1999):

$S=1-\left[\frac{1}{360^{\circ}} \sum_{i=1}^{n} \Delta \phi_{i}\left(\sin \theta_{i}\right)^{3.3}\right]$,

where $S$ is the shielding value, $\Delta \phi_{i}$, the horizontal spacing between azimuths $=30^{\circ}$, and $\theta_{i}$ is the inclination in degrees from the horizontal of the object doing the shielding.

Snow shielding can diminish the measured surfaceexposure age by decreasing the amount of cosmogenic radiation that reaches the rock surface. Although snow depths and densities for the past $25 \mathrm{ka}$ are not known for the Colorado and west-central Wyoming moraine sites, we applied approximate Sierra Nevadan values of effective wetness $\left(\bar{W}_{\text {eff }}\right)$ to examine the hypothetical effect of snow shielding on the apparent (measured) ages of boulders on Pinedale moraines.

Effective wetness is the ratio of the surface area of a lake at any particular time to its historical mean surface area. One way to approximate changes in snow cover is to determine changes in effective wetness for a lake at the terminus of a surface-water system containing a Pinedale or Tioga glacier. Benson et al. (2004) determined the average effective wetness $\left(\bar{W}_{\text {eff }}=4.3\right)$ of the Sierra Nevada for the past $25 \mathrm{ka}$, using changes in lake size documented in the Lahontan Basin. The Sierran values of $\bar{W}_{\text {eff }}$ are not strictly applicable to many of the sites mentioned in this paper. However, to illustrate the possible importance of snow shielding on moraine-crest boulder ages, we applied the $\bar{W}_{\text {eff }}$ value associated with the Sierra Nevada area to our study sites.

In order to apply Sierran values of $\bar{W}_{\text {eff }}$ to Colorado sites, we scaled historical snow-depth data from Colorado and Wyoming snow-course sites located at elevations and topographic settings similar to our sampling sites using a scaling factor of 4.3. We used snow densities of 0.24 to $0.27 \mathrm{~g} \mathrm{~cm}^{-3}$ and the following equation (Gosse and Phillips, 2001) to calculate the

Table 2

Comparison of ${ }^{10} \mathrm{Be}$ and ${ }^{36} \mathrm{Cl}$ ages of three boulders from north-central Colorado calculated using different cosmogenic production values

\begin{tabular}{|c|c|c|c|c|}
\hline Erosion rate & $0.0 \mathrm{~mm} / \mathrm{ka}$ & $1.0 \mathrm{~mm} / \mathrm{ka}$ & $0.0 \mathrm{~mm} / \mathrm{ka}$ & $1.0 \mathrm{~mm} / \mathrm{ka}$ \\
\hline${ }^{10} \mathrm{Be}$ prod rate & $5.1 \mathrm{at} / \mathrm{g} / \mathrm{yr}$ & $\begin{array}{l}5.1 \mathrm{at} / \mathrm{g} / \mathrm{yr} \\
{ }^{10} \mathrm{Be} \text { ages }\end{array}$ & $5.4 \mathrm{at} / \mathrm{g} / \mathrm{yr}$ & $5.4 \mathrm{at} / \mathrm{g} / \mathrm{yr}$ \\
\hline Sample No. & ${ }^{10} \mathrm{Be}$ age & ${ }^{10} \mathrm{Be}$ age & ${ }^{10} \mathrm{Be}$ age & ${ }^{10} \mathrm{Be}$ age \\
\hline NSV-1-4 & $20.6 \pm 1.3$ & $20.6 \pm 1.3$ & $19.4 \pm 1.2$ & $19.4 \pm 1.2$ \\
\hline RF-1-5 & $21.0 \pm 1.2$ & $21.0 \pm 1.2$ & $19.8 \pm 1.1$ & $19.8 \pm 1.1$ \\
\hline RF-1-9 & $19.2 \pm 1.1$ & $19.3 \pm 1.1$ & $18.1 \pm 1.0$ & $18.1 \pm 1.0$ \\
\hline${ }^{36} \mathrm{Cl}$ prod rate $(\mathrm{Ca})$ & $48.8 \mathrm{at} / \mathrm{g} / \mathrm{yr}$ & $48.8 \mathrm{at} / \mathrm{g} / \mathrm{yr}$ & $66.8 \mathrm{at} / \mathrm{g} / \mathrm{yr}$ & $66.8 \mathrm{at} / \mathrm{g} / \mathrm{yr}$ \\
\hline${ }^{36} \mathrm{Cl}$ prod rate $(\mathrm{K})$ & $170 \mathrm{at} / \mathrm{g} / \mathrm{yr}$ & $\begin{array}{l}170 \text { at } / \mathrm{g} / \mathrm{yr} \\
{ }^{36} \mathrm{Cl} \text { ages }\end{array}$ & $154 \mathrm{at} / \mathrm{g} / \mathrm{yr}$ & $154 \mathrm{at} / \mathrm{g} / \mathrm{yr}$ \\
\hline Sample No. & ${ }^{36} \mathrm{Cl}$ age & ${ }^{36} \mathrm{Cl}$ age & ${ }^{36} \mathrm{Cl}$ age & ${ }^{36} \mathrm{Cl}$ age \\
\hline NSV-1-4 & $17.3 \pm 0.9$ & $17.1 \pm 0.9$ & $18.4 \pm 0.9$ & $18.2 \pm 0.9$ \\
\hline RF-1-5 & $18.3 \pm 0.9$ & $18.0 \pm 0.9$ & $19.3 \pm 0.9$ & $18.9 \pm 0.9$ \\
\hline RF-1-9 & $17.8 \pm 1.0$ & $17.4 \pm 1.0$ & $18.4 \pm 1.0$ & $17.9 \pm 1.0$ \\
\hline
\end{tabular}

The ${ }^{10} \mathrm{Be}$ production rate of $5.1 \mathrm{at} / \mathrm{g} / \mathrm{yr}$ at SLHL is from Stone (2000), and the $5.4 \mathrm{at} / \mathrm{g} / \mathrm{yr}$ rate is the average of two high-altitude mid-latitude sites (Klein and Gosse, 2002; Kubik and Ivy-Ochs, 2004). Muonic production of ${ }^{10} \mathrm{Be}$ was calculated from equations 3 and 4 in Stone (2000) with the fraction of spallogenic production at sea level set to $0.974 .{ }^{36} \mathrm{Cl}$ production rates of $48.8(\mathrm{Ca})$ and $170(\mathrm{~K})$ at $/ \mathrm{g} / \mathrm{yr}$ are from Stone et al. (1996) and Evans et al. (1997). ${ }^{36} \mathrm{Cl}$ production rates of $66.8(\mathrm{Ca})$ and $154(\mathrm{~K}) \mathrm{at} / \mathrm{g} / \mathrm{yr}$ are from Phillips et al. (1996b, 2001). Thermal and epithermal production of ${ }^{36} \mathrm{Cl}$ is based on Phillips et al. (2001). Muonic production of ${ }^{36} \mathrm{Cl}$ is based on Evans et al. (1998). The use of the ${ }^{10} \mathrm{Be}$ production rate of 5.4 at/g/yr and the ${ }^{36} \mathrm{Cl}$ production rates of $66.8(\mathrm{Ca})$ and $154(\mathrm{~K}) \mathrm{at} / \mathrm{g} / \mathrm{yr}$ results in the most similar sets of surface-exposure ages for the three boulders. 
fraction of the cosmic-ray flux reaching the rock surface beneath the snow cover (snow course data are given in Appendix C):

$S_{\text {snow on } r x}=\frac{1}{12} \sum_{i=1}^{i=12} \mathrm{e}^{-\left(\left[D_{\text {snow }, i}-D_{r x}\right] \times \rho_{\text {snow }, i}\right) / \mathrm{A}_{f}}$,

where $S_{\text {snow on } r x}$ is the annual snow shielding on a rock $(r x), D_{\text {snow }, i}-D_{r x}$ is the monthly amount of snow cover on the rock surface, $\rho_{\text {snow }, i}$ is the density of the snow pack, and $A_{f}$ is the snow-free cosmic-ray-flux attenuation length. Snow shielding values ranged from 0.977 to 1.000 for Wyoming boulders, from 0.891 to 1.000 for southwestern Colorado boulders, and from 0.853 to 0.977 for north-central Colorado boulders. This calculation only approximates the effects of snow shielding of fast neutrons on exposure ages, and does not account for the additional effect of absorption of thermal neutrons which could increase the average production rate of ${ }^{36} \mathrm{Cl}$.

\section{Results}

\subsection{Comparison of surface-exposure ages of Colorado and Wyoming moraine-crest boulders}

The surface-exposure ages of Colorado and westcentral Wyoming moraine-crest boulders are shown in Table 3 as a function of the rock-surface erosion rate, with and without hypothetical corrections for snow shielding. When samples with anomalously old (inheritance) and anomalously young ages are excluded, and when snow shielding and rock-surface-erosion rates are set to zero, the mean ages ${ }^{3}$ of the Pinedale terminal moraines in southwestern Colorado, north-central Colorado, and west-central Wyoming are $18.9{ }^{36} \mathrm{Cl} \mathrm{ka}$, $18.4{ }^{36} \mathrm{Cl} \mathrm{ka}$, and $19.6{ }^{10} \mathrm{Be} \mathrm{ka}$, respectively (Table 3, Fig. 5). With the same qualifications, the age range of boulders on terminal moraines in each of the three areas is $21.5-16.6{ }^{36} \mathrm{Cl} \mathrm{ka}, 20.9-16.5{ }^{36} \mathrm{Cl} \mathrm{ka}$, and $22.9-16.7$

${ }^{10}$ Be ka (Table 3, Fig. 5).

Studies of rhyolites in southern Colorado (Caine, 1979) and granodiorites in north-central Colorado (Benedict, 1993) have shown that boulder surfaces erode at a rate of $\sim 1 \mathrm{~mm} / \mathrm{ka}$. Applying this weathering rate to boulders in southwestern and north-central Colorado decreases the exposure ages by $30-570 \mathrm{yr}$ and by $180-1080 \mathrm{yr}$, respectively. However, application of this weathering rate to exposure ages of Wyoming boulders yields increases of only 30-60 yr (Table 3). Snow shielding has little effect on the Wyoming boulders because of their large size (height data are given in

\footnotetext{
${ }^{3}$ Cosmogenic ages are reported to 3 significant figures for the purpose of sample comparison. The ages are accurate to only two significant figures.
}

Appendix A), and it causes only minor increases in the ages of southwestern Colorado boulders. In contrast, snow shielding causes relatively large increases in ages of boulders from north-central Colorado (Table 3, Fig. 6).

\subsection{Interpretation of moraine ages from boulder surface- exposure ages}

Interpretation of moraine ages from boulder surfaceexposure ages, which generally span a few thousand years at any locality, is largely a function of the importance assigned to the various processes involved in glacial erosion and transport and the post-depositional modification of moraines. Those processes include: exposure of the boulder to cosmic radiation prior to glacial transport (inheritance), boulder erosion during and after transport to the moraine, boulder rotation, and boulder shielding (snow, sediment, topographic, etc.). Inheritance produces surface-exposure ages that are too old, whereas shielding and boulder rotation produce surface-exposure ages that are too young. Rock-surface erosion produces ${ }^{10} \mathrm{Be}$ ages that are too young and ${ }^{36} \mathrm{Cl}$ ages that are too old (for erosion of $<30 \mathrm{~cm}$ of rock surface; see Fig. 6 in Benson et al., 2003). Boulder geometry can also affect its surfaceexposure age. Production rates within rounded boulders may be $10-12 \%$ lower than production rates below the surface of an infinite flat target (Masarik et al., 2000; Masarik and Wieler, 2003).

Researchers have used boulder-age distributions to estimate moraine ages in different ways. In a study of Tioga and pre-Tioga moraines on the eastern slope of the Sierra Nevada, Phillips et al. (1996a) concluded that the maximum end of the ${ }^{36} \mathrm{Cl}$ age distribution represented the time of moraine formation; i.e., they assumed that the younger surface-exposure ages were of boulders that had been exhumed by post-depositional erosion.

In a study of late-Pleistocene moraine sequences in the Yellowstone National Park and the Wallowa Lake area, Oregon, Licciardi et al. (2001, 2004) concluded that, given the analytical and other potential geologic uncertainties (e.g., prior exposure, rock-surface erosion, boulder rotation, shielding), that the mean boulderexposure age was the best estimate of landform age.

In a study of the Pinedale moraines near the downvalley end of Fremont Lake, Wyoming, Gosse et al. (1995) initially suggested that the range of ${ }^{10} \mathrm{Be}$ ages represented the several millennia during which boulders were delivered to the moraines. Gosse et al. (2003) later noted that boulder ages decrease from the front of the moraine to the back, and suggested that the first boulders to arrive at the moraine may have had an inherited component; i.e., the glacier first eroded regolith that had been exposed to cosmic radiation prior to glaciation. 
Table 3

Comparison of moraine-crest boulder surface-exposure ages in southwestern Colorado, north-central Colorado, and west-central Wyoming. Colorado boulder ages are ${ }^{36} \mathrm{Cl}$ ages and Wyoming boulder ages are ${ }^{10} \mathrm{Be}$ ages. Ages in brackets probably reflect previous exposure (cosmogenic inheritance). A sample with an abnormally young age is in parentheses. E= rock-surface erosion rate. SL, HL, and FL are the Soda Lake, Half Moon Lake, and Fremont Lake lobes at the type locality of the Pinedale Till. 1 refers to a terminal moraine and 2 through 5 indicate recessional moraines, with distance from the terminus increasing with number. Averages are of all southwestern-Colorado Pinedale terminal moraines, all north-centralColorado Pinedale terminal moraines, all west-central-Wyoming Pinedale terminal moraines, and all west-central-Wyoming Pinedale recessional moraines

\begin{tabular}{|c|c|c|c|c|c|c|}
\hline & & $\mathrm{E}=0 \mathrm{~mm} / \mathrm{kyr}$ & $\mathrm{E}=1 \mathrm{~mm} / \mathrm{kyr}$ & $\mathrm{E}=0 \mathrm{~mm} / \mathrm{kyr}$ & $\mathrm{E}=1 \mathrm{~mm} / \mathrm{kyr}$ & $\mathrm{E}=0 \mathrm{~mm} / \mathrm{kyr}$ \\
\hline & & $\begin{array}{l}\text { No snow } \\
\text { age (ka) }\end{array}$ & $\begin{array}{l}\text { No snow } \\
\text { age (ka) }\end{array}$ & $\begin{array}{l}\text { Snow shielded } \\
\text { age }(\mathrm{ka})\end{array}$ & $\begin{array}{l}\text { Snow shielded } \\
\text { age }(\mathrm{ka})\end{array}$ & $\begin{array}{l}1-\sigma \text { error } \\
(\mathrm{ka})\end{array}$ \\
\hline \multicolumn{7}{|c|}{ Southwestern Colorado } \\
\hline \multicolumn{7}{|c|}{ Continental Reservoir } \\
\hline CR-01 & & 20.0 & 19.4 & 20.8 & 20.2 & 1.0 \\
\hline CR-02 & & 21.1 & 19.6 & 22.4 & 21.8 & 1.1 \\
\hline CR-03 & & 19.7 & 19.2 & 22.2 & 21.6 & 1.0 \\
\hline \multicolumn{7}{|c|}{ Hogback Mountain Inner moraine } \\
\hline HM-01 & & 17.7 & 17.5 & 18.2 & 18.0 & 0.9 \\
\hline HM-02 & & 19.2 & 19.2 & 19.9 & 19.9 & 1.0 \\
\hline HM-03 & & 17.3 & 17.2 & 18.0 & 17.8 & 0.9 \\
\hline HM-04 & & 21.0 & 20.6 & 21.0 & 20.7 & 1.0 \\
\hline \multicolumn{7}{|c|}{ Middle moraine } \\
\hline HM-05 & & 21.5 & 20.8 & 21.5 & 20.8 & 1.1 \\
\hline HM-06 & & 18.5 & 18.3 & 19.2 & 19.0 & 0.9 \\
\hline HM-07 & & 16.7 & 16.5 & 17.6 & 17.3 & 0.8 \\
\hline HM-08 & & 19.4 & 18.9 & 19.6 & 19.2 & 1.0 \\
\hline \multicolumn{7}{|c|}{ Outer moraine } \\
\hline HМ-09 & & 16.6 & 16.1 & 16.8 & 16.3 & 0.8 \\
\hline HM-10 & & 17.8 & 17.6 & 18.7 & 18.5 & 0.9 \\
\hline HM-11 & & {$[48.8]$} & & & & \\
\hline HM-12 & & 18.1 & 17.9 & 18.7 & 18.5 & 0.9 \\
\hline Average & & 18.9 & 18.5 & 19.6 & 19.2 & \\
\hline \multicolumn{7}{|c|}{ North-Central Colorado } \\
\hline \multicolumn{7}{|c|}{ Middle Boulder Crk } \\
\hline MBC-01-1 & & 17.5 & 16.5 & 19.1 & 17.9 & 0.9 \\
\hline MBC-01-2 & & 20.9 & 20.1 & 22.5 & 21.6 & 1.0 \\
\hline \multicolumn{7}{|c|}{ North St. Vrain Crk } \\
\hline NSV-01-4 & & 18.4 & 18.2 & 18.9 & 18.7 & 0.9 \\
\hline \multicolumn{7}{|c|}{ Roaring Fork Crk } \\
\hline RF-01-2 & & {$[25.8]$} & & & & \\
\hline RF-01-3 & & 19.3 & 18.8 & 22.1 & 21.5 & 1.0 \\
\hline RF-01-5 & & 19.3 & 18.9 & 21.8 & 21.3 & 1.0 \\
\hline RF-01-6 & & 16.5 & 16.3 & 19.1 & 18.9 & 0.8 \\
\hline RF-01-7 & & 17.2 & 16.9 & 20.2 & 19.8 & 0.9 \\
\hline RF-01-9 & & 18.4 & 17.9 & 21.6 & 20.9 & 0.9 \\
\hline Average & & 18.4 & 17.9 & 20.7 & 20.1 & \\
\hline \multicolumn{7}{|c|}{ Pinedale Wyoming } \\
\hline 91-003 & SL1 & 19.0 & 19.0 & 19.0 & 19.0 & 0.7 \\
\hline $91-003$ & & 18.8 & 18.8 & 18.8 & 18.8 & 0.7 \\
\hline $91-004$ & & {$[22.8]$} & & & & \\
\hline $91-035$ & FL1 & 21.1 & 21.1 & 21.6 & 21.6 & 0.9 \\
\hline $91-035$ & & 21.0 & 21.1 & 21.5 & 21.6 & 0.9 \\
\hline $92-108-1$ & & 22.6 & 22.7 & 23.2 & 23.2 & 0.9 \\
\hline
\end{tabular}


Table 3 (continued)

\begin{tabular}{|c|c|c|c|c|c|c|}
\hline & & $\mathrm{E}=0 \mathrm{~mm} / \mathrm{kyr}$ & $\mathrm{E}=1 \mathrm{~mm} / \mathrm{kyr}$ & $\mathrm{E}=0 \mathrm{~mm} / \mathrm{kyr}$ & $\mathrm{E}=1 \mathrm{~mm} / \mathrm{kyr}$ & $\mathrm{E}=0 \mathrm{~mm} / \mathrm{kyr}$ \\
\hline & & $\begin{array}{l}\text { No snow } \\
\text { age (ka) }\end{array}$ & $\begin{array}{l}\text { No snow } \\
\text { age (ka) }\end{array}$ & $\begin{array}{l}\text { Snow shielded } \\
\text { age (ka) }\end{array}$ & $\begin{array}{l}\text { Snow shielded } \\
\text { age (ka) }\end{array}$ & $\begin{array}{l}1-\sigma \text { error } \\
\text { (ka) }\end{array}$ \\
\hline $91-032$ & & 22.9 & 23.0 & 22.9 & 23.0 & 1.0 \\
\hline $92-105-2$ & & 19.5 & 19.6 & 20.0 & 20.1 & 0.8 \\
\hline $92-110-1$ & & 19.8 & 19.9 & 20.3 & 20.4 & 0.8 \\
\hline $92-107-1$ & & 16.7 & 16.8 & 17.1 & 17.2 & 0.7 \\
\hline $92-106-2$ & & 20.2 & 20.2 & 20.7 & 20.7 & 0.8 \\
\hline 91-029 & & 18.5 & 18.5 & 18.5 & 18.5 & 0.7 \\
\hline 91-009 & & 18.5 & 18.6 & 19.0 & 19.0 & 0.7 \\
\hline 91-041 & & 17.5 & 17.5 & 17.6 & 17.6 & 0.7 \\
\hline $91-013$ & & 20.1 & 20.2 & 20.1 & 20.2 & 0.8 \\
\hline $91-031$ & & 20.6 & 20.6 & 21.0 & 21.1 & 0.8 \\
\hline $91-033$ & & 17.8 & 17.8 & 18.2 & 18.3 & 0.7 \\
\hline 91-010 & & 16.9 & 16.9 & 17.5 & 17.5 & 0.7 \\
\hline 91-030 & & $(15.1)$ & & & & \\
\hline $92-117$ & HL1 & 20.6 & 20.6 & 20.6 & 20.6 & 0.9 \\
\hline $92-119$ & & 20.2 & 20.3 & 20.7 & 20.8 & 0.8 \\
\hline Average & & 19.6 & 19.6 & 19.9 & 20.0 & \\
\hline $93-308$ & FL2 & [31.6] & & & & \\
\hline $93-306$ & FL2 & [22.9] & & & & \\
\hline $92-123$ & HL2 & 16.9 & 16.9 & 16.9 & 16.9 & 0.7 \\
\hline $92-155$ & HL2 & 16.8 & 16.8 & 17.2 & 17.2 & 0.7 \\
\hline $92-129$ & HL3 & 17.8 & 17.8 & 18.4 & 18.5 & 0.7 \\
\hline $92-124$ & & 16.5 & 16.5 & 16.5 & 16.5 & 0.7 \\
\hline $91-020$ & FL4 & 16.3 & 16.4 & 16.7 & 16.8 & 0.7 \\
\hline $92-127$ & & 16.4 & 16.5 & 16.6 & 16.6 & 0.7 \\
\hline $92-130$ & HL5 & 17.7 & 17.7 & 17.7 & 17.7 & 0.7 \\
\hline $91-024$ & & 17.3 & 17.3 & 17.3 & 17.3 & 0.7 \\
\hline $92-156$ & & 17.3 & 17.3 & 17.4 & 17.5 & 0.7 \\
\hline $91-026$ & & 15.2 & 15.2 & 15.2 & 15.2 & 0.6 \\
\hline Average & & 17.6 & 17.6 & 17.8 & 17.8 & \\
\hline
\end{tabular}

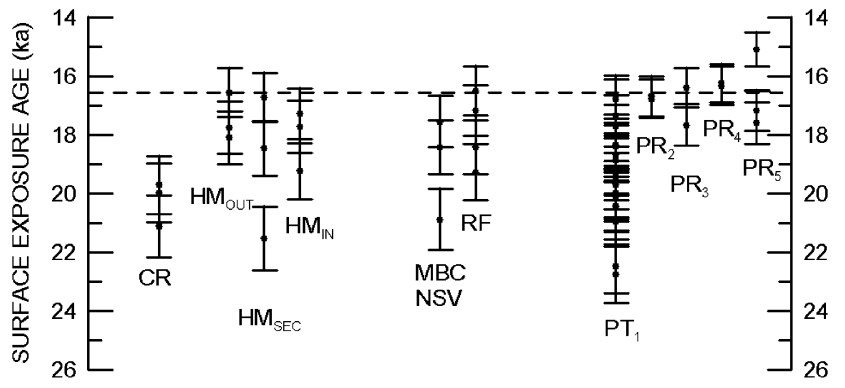

Fig. 5. Surface-exposure ages of moraine-crest boulders from Continental Reservoir (CR), Hogback Mountain (HM), Middle Boulder Creek (MBC), North St. Vrain (NSV), Roaring Fork (RF), Pinedale terminal (PT) and Pinedale recessional (PR) sites in Colorado and Wyoming (see Fig. 1 for site locations and Figs. 2-4 for sample locations). $\mathrm{HM}_{\mathrm{OUT}}, \mathrm{HM}_{\mathrm{SEC}}$, and $\mathrm{HM}_{\mathrm{MIN}}$ refer to the outermost, second outermost, and innermost moraines at Hogback Mountain. The surface-exposure age of each sample and its $\pm 1-\sigma$ value are illustrated with a filled circle and error bars, respectively. Rock-surface erosion rates and snow shielding values were set to zero in the calculation of the surface-exposure age. The horizontal dashed line indicates estimated time of glacial retreat at all three sites.

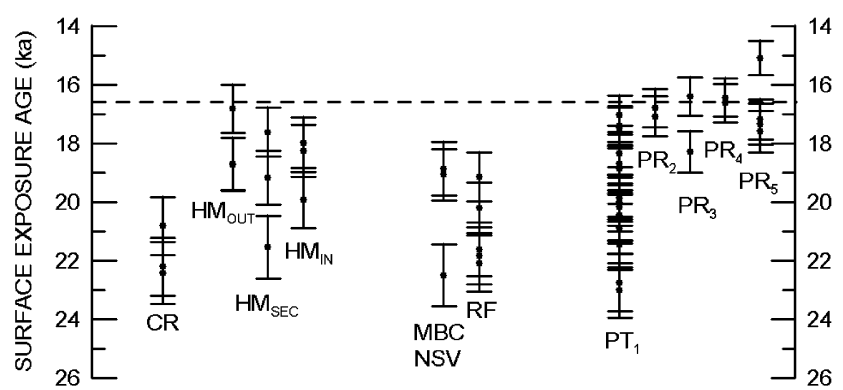

Fig. 6. Surface-exposure ages of moraine-crest boulders from Continental Reservoir (CR), Hogback Mountain (HM), Middle Boulder Creek (MBC), North St. Vrain (NSV), Roaring Fork (RF), Pinedale terminal $\left(\mathrm{PT}_{1}\right)$ and Pinedale recessional $(\mathrm{PR})$ sites in Colorado and Wyoming (see Fig. 1 for site locations and Figs. 2-4 for sample locations). The surface-exposure age of each sample and its $\pm 1-\sigma$ value are illustrated with a filled circle and error bars, respectively. Rocksurface erosion rates were set to zero and snow shielding was set to 4.3 times modern snow course values in the calculation of the surfaceexposure age. The horizontal dashed line indicates estimated time of glacial retreat at all three sites. 


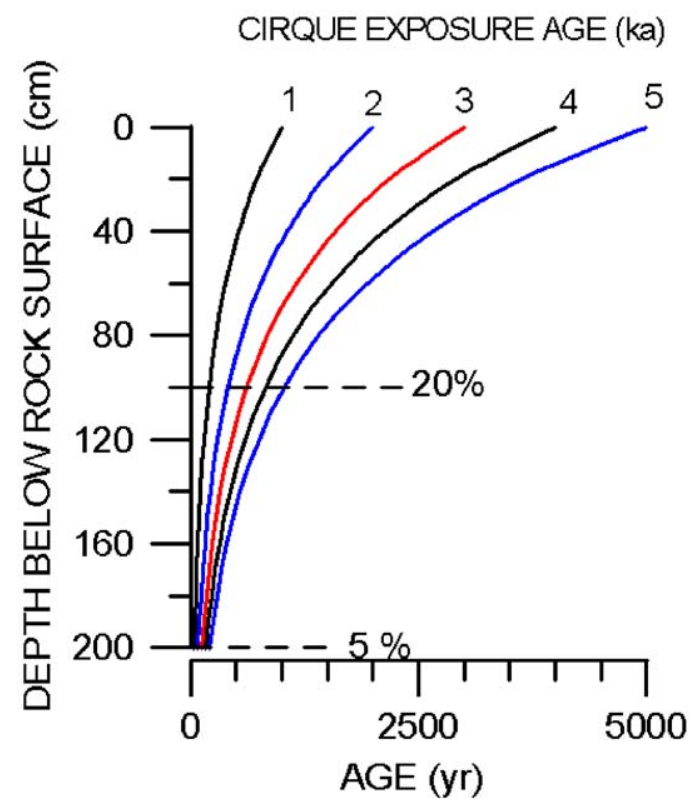

Fig. 7. Modeled cosmogenic ${ }^{10} \mathrm{Be}$-age profiles for the cirque wall at Butler Gulch site north-central Colorado. The cirque wall has a $30^{\circ}$ slope. Cirque-wall exposure times ranged from 1 to $5 \mathrm{ka}$. If a $2-\mathrm{m}$ cubic boulder was eroded from the cirque wall, a sample from the center of any of the four faces bordering the outer face of the cube would possess $20 \%$ of the cosmogenic exposure received by the outer face. The boulder face opposite the outer face would possess $5 \%$ of the cosmogenic exposure received by the outer face.

Inheritance is obvious when the age of one boulder is much older than the ages of other boulders on the moraine (e.g., HM-11, RF-01-02, 93-306, 93-308 in Table 3). Inheritance, however, is not always discernible. For example, if we examine theoretical ${ }^{10} \mathrm{Be}$ production profiles for cirque or valley walls with a slope of $30^{\circ}$ after $1,2,3,4$, and $5 \mathrm{ka}$ of exposure, as much as $5 \%$ of rock-surface production exists even at a depth of $\sim 2 \mathrm{~m}$ (Fig. 7). ${ }^{4}$ A boulder $\leqslant 2 \mathrm{~m}$ in thickness has inheritance on all its faces; e.g., if the boulder initially has a cubic form, the outer face of the boulder is the site of greatest cosmogenic production, but the centers of the four faces adjacent to the outer face also receive $20 \%$ of the exposure received by the outer face (Fig. 7). A 2-mdiameter boulder on a moraine crest would have had to begin its existence as a 6-m-diameter rock to lose most $(95-100 \%)$ of its inherited ${ }^{10} \mathrm{Be}$. Englacial transport that rounds boulders but does not remove all traces of inherited cosmogenic nuclides requires analysis of a large number of samples to accurately date the end stage of moraine formation. For example, in the case of a

\footnotetext{
${ }^{4}$ This calculation was done using a computer program developed by G. Landis. The calculation was made for a location about half way up the cirque wall (elevation $\sim 3800 \mathrm{~m}$ ) at the Butler Gulch site in northern Colorado (39.75 N, 105.87 W). Topographic shielding was included in the calculation.
}

$250-\mathrm{cm}^{2}$ sample collected from a 2-m-diameter spherical boulder that possesses cosmogenic inheritance, the probability of obtaining a sample having a minimum inheritance is 1 in 500. A sample having minimum inheritance would come from that part of the boulder that initially faced into the cirque or valley wall, and the probability of sampling that area is the ratio of the surface area of the sample to the total surface area of the 2-m boulder.

There is no simple or completely reliable method of detecting the existence of inheritance. Gosse et al. (2003) have suggested that the ${ }^{26} \mathrm{Al} /{ }^{10} \mathrm{Be}$ ratio can be used to indicate the presence of inheritance. "If a rock was exposed in a valley prior to glaciation, then buried by ice and till over a few glaciations, then eventually plucked and delivered to the terminal (moraine), the ratio would reflect this burial. The samples with older ages (higher ${ }^{10} \mathrm{Be}$ concentrations) tend to have lower ${ }^{26} \mathrm{Al} /{ }^{10} \mathrm{Be}$ ratios." Based on ${ }^{26} \mathrm{Al} /{ }^{10} \mathrm{Be}$ trends that decrease with age on the moraine, Gosse et al. (2003) suggested that the boulders deposited on the first Pinedale moraines formed in the Fremont Lake basin may have had a relatively higher inheritance because the glacier eroded material that was exposed to cosmic radiation prior to the Pinedale glaciation. They concluded that the age distribution of boulders on Pinedale moraines is due to a combination of inheritance and the time span over which the boulders were delivered.

Our ability to date moraine formation depends on the timing and spatial characteristics of glacier advances. If a terminal moraine complex consists of a sequence of moraines with the oldest moraine at the distal edge of the complex and the youngest moraine on the upvalley side of the complex (e.g., the Pinedale terminal moraine sequence in the Fremont Lake basin, Wyoming, and the Pinedale terminal moraine sequence at the Hogback Mountain site in southwestern Colorado), it may be possible to date the duration of moraine formation.

If, on the other hand, the glacier readvanced after receding from an initial terminal position, it may either erode or bury older moraines (e.g., the Pinedale terminal moraine at the Continental Reservoir site in southwestern Colorado). Thus, the duration of moraine formation is difficult to determine in the case of high moraines composed of thick deposits of till such as those found at the Continental Reservoir site (Table 4, Fig. 2B). The 30-m-high moraine at this site may have resulted from buttressing of several successive glacier advances and the only boulders suitable for surfaceexposure ages on the crest of the 30-m-high landform were deposited during the last and most extensive advance. In addition, steep distal slopes may be subject to downslope sediment transfer and boulder rotation resulting in the lowering of the moraine crest (Hallet and Putkonen, 1994). 
Table 4

Estimated moraine thicknesses for Colorado and Wyoming sites

\begin{tabular}{lc}
\hline Site & Thickness (m) \\
\hline Hogback Mountain, CO & $5-10$ \\
Continental Reservoir, CO & $20-30$ \\
Middle Boulder Creek, CO & $10-15$ \\
North St. Vrain, CO & $10-15$ \\
Roaring Fork, CO & $15-30$ \\
Fremont Lake, WY & $10-65$ \\
\hline
\end{tabular}

As many as seven moraines make up the terminal moraine complex at the Hogback Mountain site (Fig. 2A). Each moraine is only 5- to $10-\mathrm{m}$ high (Table 4). Samples were taken from the two most distal moraines and from the most proximal moraine (Fig. 2A). Surface-exposure ages for moraine-crest boulders at the Hogback Mountain site range from 21.5 to $16.6{ }^{36} \mathrm{Cl} \mathrm{ka}\left(20.8\right.$ to $16.3{ }^{36} \mathrm{Cl}$ ka when corrected for possible snow shielding and rock erosion, Table 3). However, the age data (Figs. 5 and 6) do not systematically vary with moraine position, suggesting that either the moraines were deposited during a very brief time (such that the accuracies of the surface-exposure ages do not allow us to distinguish between the moraines) or that factors such as differential inheritance are affecting the age distributions. A similar scatter in the boulder ages of recessional moraines is observed in Pinedale data from the Fremont Lake basin; i.e., there is a $4 \%$ coefficient of variation about the mean age of all recessional moraines.

\subsection{Timing of glacier retreat}

We suggest, following Gosse et al. (2003) and Gosse (2004), that the youngest surface-exposure ages (excluding obvious outliers) from moraine-crest boulders in a recessional moraine complex should approximately date the onset of glacier recession. The time of initial retreat is the only quasi-instantaneous event that can be derived from the age distribution of moraine-crest boulders. This implies that older boulder dates from the same moraine crest most likely reflect inheritance. At Pinedale, Wyoming, the youngest two surface-exposure ages of boulders on the crest(s) of the terminal moraine are 16.7 and $16.9{ }^{10} \mathrm{Beka}\left(17.2\right.$ and $17.5{ }^{10} \mathrm{Be} \mathrm{ka}$ when corrected for snow shielding and rock erosion, Table 3 ). These surface-exposure ages are in general agreement with surface-exposure ages on recessional moraines in the Fremont Lake (FL) and Half Moon Lake (HL) areas (Table 3, Figs. 5 and 6), supporting the concept that minimum surface-exposure ages indicate times of glacier retreat (Gosse et al., 1995, 2003).
At the Hogback Mountain site in southwestern Colorado, the youngest two surface-exposure ages are 16.6 and $16.7 \mathrm{ka}$ (16.3 and $17.3 \mathrm{ka}$ when corrected for snow shielding and rock erosion, Table 3 ). In northcentral Colorado, the youngest two surface-exposure ages at the Roaring Fork site are 16.5 and $17.2{ }^{36} \mathrm{Cl} \mathrm{ka}$ (18.9 and $19.8{ }^{36} \mathrm{Cl}$ ka when corrected for snow shielding and rock erosion, Table 3). Thus, the data from the Fremont Lake basin in Wyoming and the Hogback Mountain site in southwestern Colorado suggest that retreat of Pinedale glaciers occurred nearly synchronously at $\sim 16.8 \pm 0.3 \mathrm{ka}$ at these localities, the latitudes of which are separated by $470 \mathrm{~km}$. The relatively small number of surface-exposure dates from north-central Colorado and the lack of prehistoric snow-thickness data preclude us from establishing an accurate estimate of glacier retreat in this region.

\section{Conclusions}

The data presented in this paper indicate that alpine glaciers in north-central and southwestern Colorado and west-central Wyoming achieved their maximum lengths during the LGM. Recession from terminal positions occurred at $\sim 16.8 \pm 0.3 \mathrm{ka}$ in southwestern Colorado and west-central Wyoming.

To a great extent, the data presented in this paper support the conclusion of Licciardi et al. (2004) that widespread glacier retreat began $\sim 17 \mathrm{ka}$ in the western US. However, our data do not support their conclusion that the initial deglaciation of the southern region of the western US occurred between 20 and $21{ }^{10} \mathrm{Be}$ ka. Instead, our data indicate that glacier retreat in southwestern Colorado and west-central Wyoming began $\sim 16.8 \pm 0.3 \mathrm{ka}$.

Rock-surface erosion does not greatly affect the surface-exposure ages of relatively young $(<30 \mathrm{cal} \mathrm{ka})$ boulders. Thus, if boulders are so large as to preclude burial by snow and loess, and if they were not exhumed, the principal sources of error in surface-exposure age are inheritance and perhaps geometry. Production rates within rounded boulders may be $10-12 \%$ lower than production rates below the surface of an infinite flat target (Masarik et al., 2000; Masarik and Wieler, 2003).

Two other factors could significantly alter some of the glacial chronologies presented in this paper. If, for example, a ${ }^{10} \mathrm{Be}$ production rate of $5.1 \mathrm{at} / \mathrm{g} / \mathrm{yr}$ is used in the calculations of surface-exposure age, the ages listed in Table 3 and discussed previously should be increased by $6 \%$; i.e., a $16.8{ }^{10} \mathrm{Be} \mathrm{ka}$ age for glacier retreat becomes $17.8{ }^{10} \mathrm{Be}$ ka. In addition, snow shielding may have diminished the surface-exposure ages of small Colorado moraine-crest boulders by more than $1 \mathrm{ka}$ at some sites. 
Thus, the cumulative uncertainty in age assignment makes it difficult to compare boulder surface-exposure ages with the timing of phenomena such as D-O oscillations and Heinrich events. Until these factors can be accurately evaluated for individual study areas, we urge caution in correlating moraine ages obtained using cosmogenic surface-exposure ages with climatic fluctuations documented in well-dated ice cores and Atlantic sediment records. It follows that the chronologies of moraine formation and glacier recession presented in this paper should be considered as tentative approximations.

\section{Acknowledgments}

Terry Thomas prepared the southwestern Colorado samples for $\mathrm{Cl}$ isotope determinations and performed the major and trace metal analyses. We also thank Alex Blum, Rich McDonald, Stephen Porter, Joe Licciardi, and Ken Pierce for reviewing earlier versions of the manuscript. Jeremy Havens and Lisa Ramirez Rukstales were responsible for much of the graphics. The use of trade, firm or brand names in this paper does not constitute endorsement by the US Geological Survey.

\section{Appendix A}

For site and sample data see Table 5.

Table 5

Site and sample data. Height refers to distance above ground surface

\begin{tabular}{|c|c|c|c|c|c|c|c|c|c|c|}
\hline \multicolumn{6}{|c|}{ Site and sample data. Height refers to distance above ground surface } & \multirow{2}{*}{$\begin{array}{l}91-041 \\
91-013 \\
91-031\end{array}$} & \multirow{2}{*}{$\begin{array}{l}2360 \\
2302 \\
2311\end{array}$} & \multirow{2}{*}{$\begin{array}{l}250 \\
400 \\
200\end{array}$} & $\begin{array}{l}42.90 \\
42.89\end{array}$ & \multirow{2}{*}{$\begin{array}{l}5.0 \\
6.0 \\
5.0\end{array}$} \\
\hline & Elevation & Boulder & Lat. & Long. & Sample & & & & $\begin{array}{l}42.89 \\
42.89\end{array}$ & \\
\hline & (m) & height & & & thickness & $91-033$ & 2302 & 200 & 42.89 & 5.0 \\
\hline & & $(\mathrm{cm})$ & & & $(\mathrm{cm})$ & $91-010$ & 2302 & 170 & 42.89 & 4.0 \\
\hline \multirow{2}{*}{\multicolumn{11}{|c|}{ Southwestern Colorado }} \\
\hline & & & & & & & & & & \\
\hline \multicolumn{10}{|l|}{ Continental Reservoir } & 3.0 \\
\hline CR-01 & 3176 & 250 & 37.88 & 107.20 & 5.0 & $92-119$ & 2319 & 200 & 42.91 & 5.0 \\
\hline CR-02 & 3175 & 90 & 37.88 & 107.20 & 4.5 & $93-308$ & 2264 & 170 & 42.89 & 5.0 \\
\hline CR-03 & 3172 & 65 & 37.88 & 107.20 & 4.5 & $95-500$ & & 170 & 42.09 & \\
\hline \multirow{2}{*}{\multicolumn{6}{|c|}{ Hogback Mountain }} & $93-306$ & 2268 & 200 & 42.89 & 3.0 \\
\hline \multirow{2}{*}{\multicolumn{6}{|c|}{ Innermost moraine }} & $92-123$ & 2369 & 500 & 42.92 & 3.0 \\
\hline & & & & & & $92-155$ & 2375 & 200 & 42.92 & 2.5 \\
\hline $\begin{array}{l}\text { HM-01 } \\
\text { HM-02 }\end{array}$ & $\begin{array}{l}2736 \\
2722\end{array}$ & $\begin{array}{r}100 \\
90\end{array}$ & $\begin{array}{l}31.13 \\
37.73\end{array}$ & $\begin{array}{l}107.03 \\
107.03\end{array}$ & $\begin{array}{l}4.0 \\
5.0\end{array}$ & & & & & \\
\hline & $\begin{array}{l}2722 \\
2730\end{array}$ & & & & 5.0 & & & & & \\
\hline HM-03 & 2730 & 80 & 37.73 & 107.03 & 4.0 & $92-129$ & 2390 & 170 & 42.92 & 5.0 \\
\hline HM-04 & 2734 & 180 & 37.73 & 107.03 & 4.0 & $92-124$ & 2337 & 300 & 42.92 & 5.0 \\
\hline \multicolumn{6}{|l|}{ Second moraine } & $91-020$ & 2352 & 200 & 42.92 & 5.0 \\
\hline HM-05 & 2744 & 300 & 37.73 & 107.03 & 4.0 & $92-127$ & 2335 & 250 & 42.92 & 4.0 \\
\hline HM-06 & 2746 & 85 & 37.73 & 107.03 & 4.5 & & & & & \\
\hline HM-07 & 2766 & 40 & 37.73 & 107.03 & 4.0 & $92-130$ & 2341 & 500 & 42.92 & 5.0 \\
\hline \multirow[t]{2}{*}{ HM-08 } & 2714 & 155 & 37.73 & 107.03 & 4.0 & $91-024$ & 2323 & 500 & 42.92 & 10.0 \\
\hline & & & & & & $92-156$ & 2341 & 240 & 42.92 & 5.0 \\
\hline Outermost moraine & & & & & & $91-026$ & 2342 & 450 & 42.92 & 4.0 \\
\hline
\end{tabular}

Table 5 (continued)

\begin{tabular}{|c|c|c|c|c|c|}
\hline & $\begin{array}{l}\text { Elevation } \\
(\mathrm{m})\end{array}$ & $\begin{array}{l}\text { Boulder } \\
\text { height } \\
(\mathrm{cm})\end{array}$ & Lat. & Long. & $\begin{array}{l}\text { Sample } \\
\text { thickness } \\
(\mathrm{cm})\end{array}$ \\
\hline HM-11 & 2747 & 30 & 37.73 & 107.03 & 4.0 \\
\hline HM-12 & 2743 & 97 & 37.73 & 107.03 & 5.0 \\
\hline \multicolumn{6}{|c|}{ North-Central Colorado } \\
\hline \multicolumn{6}{|c|}{ Middle Boulder Crk } \\
\hline MBC-01-1 & 2680 & 60 & 39.95 & 105.52 & 3.0 \\
\hline MBC-01-2 & 2660 & 80 & 39.95 & 105.52 & 3.0 \\
\hline \multicolumn{6}{|c|}{ North St. Vrain Crk } \\
\hline NSV-01-4 & 2580 & 110 & 40.22 & 105.53 & 3.0 \\
\hline \multicolumn{6}{|c|}{ Roaring Fork Crk } \\
\hline RF-01-2 & 2600 & 140 & 40.71 & 106.55 & 3.0 \\
\hline RF-01-3 & 2620 & 120 & 40.71 & 106.55 & 2.5 \\
\hline RF-01-5 & 2640 & 150 & 40.71 & 106.56 & 2.5 \\
\hline RF-01-6 & 2640 & 90 & 40.71 & 106.56 & 2.5 \\
\hline RF-01-7 & 2660 & 50 & 40.71 & 106.56 & 2.5 \\
\hline RF-01-9 & 2660 & 160 & 40.71 & 106.56 & 2.5 \\
\hline \multicolumn{6}{|c|}{ Pinedale Wyoming } \\
\hline 91-003 & 2276 & 550 & 42.93 & & 14.0 \\
\hline $91-003$ & 2276 & 550 & 42.93 & & 14.0 \\
\hline $91-004$ & 2279 & 550 & 42.93 & & 5.0 \\
\hline $91-035$ & 2262 & 200 & 42.69 & & 2.0 \\
\hline $91-035$ & 2262 & 200 & 42.69 & & 2.0 \\
\hline $92-108-1$ & 2274 & 200 & 42.90 & & 2.0 \\
\hline $91-032$ & 2311 & 360 & 42.89 & & 5.0 \\
\hline $92-105-2$ & 2290 & 200 & 42.90 & & 3.0 \\
\hline $92-110-1$ & 2287 & 200 & 42.90 & & 4.0 \\
\hline $92-107-1$ & 2271 & 200 & 42.90 & & 2.0 \\
\hline $92-106-2$ & 2271 & 200 & 42.90 & & 2.0 \\
\hline $91-029$ & 2299 & 460 & 42.89 & & 5.0 \\
\hline 91-009 & 2310 & 200 & 42.89 & & 6.0 \\
\hline $91-041$ & 2360 & 250 & 42.90 & & 5.0 \\
\hline $91-013$ & 2302 & 400 & 42.89 & & 6.0 \\
\hline $91-031$ & 2311 & 200 & 42.89 & & 5.0 \\
\hline $91-033$ & 2302 & 200 & 42.89 & & 5.0 \\
\hline $91-010$ & 2302 & 170 & 42.89 & & 4.0 \\
\hline $91-030$ & 2305 & 200 & 42.89 & & 5.0 \\
\hline $92-117$ & 2357 & 400 & 42.92 & & 3.0 \\
\hline $92-119$ & 2319 & 200 & 42.91 & & 5.0 \\
\hline $93-308$ & 2264 & 170 & 42.89 & & 5.0 \\
\hline $93-306$ & 2268 & 200 & 42.89 & & 3.0 \\
\hline $92-123$ & 2369 & 500 & 42.92 & & 3.0 \\
\hline $92-155$ & 2375 & 200 & 42.92 & & 2.5 \\
\hline $92-129$ & 2390 & 170 & 42.92 & & 5.0 \\
\hline $92-124$ & 2337 & 300 & 42.92 & & 5.0 \\
\hline $91-020$ & 2352 & 200 & 42.92 & & 5.0 \\
\hline $92-127$ & 2335 & 250 & 42.92 & & 4.0 \\
\hline $92-130$ & 2341 & 500 & 42.92 & & 5.0 \\
\hline $91-024$ & 2323 & 500 & 42.92 & & 10.0 \\
\hline $92-156$ & 2341 & 240 & 42.92 & & 5.0 \\
\hline $91-026$ & 2342 & 450 & 42.92 & & 4.0 \\
\hline
\end{tabular}

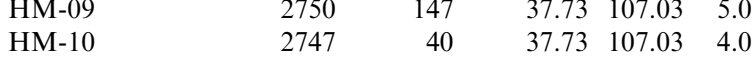




\section{Appendix B}

\section{B.1. Methods}

\section{B.1.1. ${ }^{36} \mathrm{Cl}$ determinations}

${ }^{36} \mathrm{Cl}$ values were obtained on all southwestern and north-central Colorado samples. Samples were sawn to a thickness of $2.5-3.0 \mathrm{~cm}$. Lichens and other organic matter were removed from the surface before reducing the sample to $<1 \mathrm{~mm}$ fragments by grinding. The sample was then sieved to obtain the $>150 \mu \mathrm{m}$ to $<1 \mathrm{~mm}$ size fraction. The sample was leached in $3 \% \mathrm{HNO}_{3}$ overnight to remove any secondary chloride and carbonate, rinsed in $18 \mathrm{M} \Omega$ water. The solution was brought to a basic $\mathrm{pH}$ using $1 \% \mathrm{NaOH}$, and rinsed several times in $18 \mathrm{M} \Omega$ water bringing it to a $\mathrm{pH}<7$. After oven drying at $<90{ }^{\circ} \mathrm{C}$, aliquots for chemical analyses were removed and ground to a powder using a tungsten-carbide mill.

Major elements, including $\mathrm{U}$ and $\mathrm{Th}$, were determined by X-ray fluorescence, and B and Gd were measured by prompt-gamma-emission spectrometry (see Table 6 this appendix). The chloride concentration of the samples was initially estimated with an ion-selective electrode in a Teflon diffusion cell. This initial estimate was used to determine the mass of sample to be dissolved and the amount of stable chloride carrier $\left(99.5 \%{ }^{35} \mathrm{Cl}\right)$ to be added. The chloride concentrations used for age calculations were determined by accelerator mass spectrometry (AMS) using isotope-dilution mass spectrometry.

Table 6

Chemical analyses of Colorado samples

\begin{tabular}{|c|c|c|c|c|c|c|c|c|c|c|c|c|}
\hline Major elements & $\begin{array}{l}\mathrm{SiO}_{2} \\
\text { (wt. \%) }\end{array}$ & $\begin{array}{l}\mathrm{TiO}_{2} \\
\text { (wt. \%) }\end{array}$ & $\begin{array}{l}\mathrm{Al}_{2} \mathrm{O}_{3} \\
\text { (wt. \%) }\end{array}$ & $\begin{array}{l}\mathrm{Fe}_{2} \mathrm{O}_{3}-\mathrm{T} \\
\text { (wt. \%) }\end{array}$ & $\begin{array}{l}\mathrm{MnO} \\
\text { (wt. \%) }\end{array}$ & $\begin{array}{l}\mathrm{MgO} \\
\text { (wt. \%) }\end{array}$ & $\begin{array}{l}\mathrm{CaO} \\
\text { (wt. \%) }\end{array}$ & $\begin{array}{l}\mathrm{K}_{2} \mathrm{O} \\
\text { (wt. \%) }\end{array}$ & $\begin{array}{l}\mathrm{Na}_{2} \mathrm{O} \\
\text { (wt. \%) }\end{array}$ & $\begin{array}{l}\mathrm{P}_{2} \mathrm{O}_{5} \\
\text { (wt. \%) }\end{array}$ & $\begin{array}{l}\text { LOI } \\
\text { (wt. \%) }\end{array}$ & $\begin{array}{l}\text { Total } \\
\text { (wt. \%) }\end{array}$ \\
\hline \multicolumn{13}{|c|}{ Southwestern Colorado } \\
\hline \multicolumn{13}{|c|}{ Continental Reservoir } \\
\hline CR-01 & 67.04 & 0.540 & 15.67 & 4.09 & 0.050 & 0.72 & 2.76 & 4.03 & 3.64 & 0.080 & 1.10 & 98.62 \\
\hline CR-02 & 66.43 & 0.562 & 15.77 & 4.52 & 0.063 & 0.81 & 2.78 & 4.19 & 3.56 & 0.070 & 0.93 & 98.76 \\
\hline CR-03 & 66.87 & 0.570 & 15.56 & 4.55 & 0.060 & 0.90 & 2.66 & 4.32 & 3.50 & 0.080 & 0.80 & 99.07 \\
\hline \multicolumn{13}{|c|}{ Hogback Mountain } \\
\hline \multicolumn{13}{|c|}{ Innermost moraine } \\
\hline HM-01 & 65.55 & 0.645 & 16.11 & 4.44 & 0.063 & 0.90 & 2.66 & 4.69 & 3.55 & 0.084 & 1.01 & 98.69 \\
\hline HM-02 & 66.65 & 0.635 & 15.40 & 4.29 & 0.052 & 0.77 & 2.19 & 5.09 & 3.50 & 0.078 & 1.16 & 98.66 \\
\hline HM-03 & 67.98 & 0.585 & 15.01 & 3.93 & 0.053 & 0.73 & 1.86 & 5.38 & 3.41 & 0.082 & 0.70 & 99.02 \\
\hline HM-04 & 65.50 & 0.668 & 15.48 & 4.52 & 0.058 & 0.77 & 2.23 & 4.91 & 3.37 & 0.322 & 1.29 & 97.83 \\
\hline \multicolumn{13}{|l|}{ Second moraine } \\
\hline HM-05 & 67.39 & 0.545 & 15.12 & 4.61 & 0.056 & 0.65 & 2.47 & 4.10 & 3.40 & 0.090 & 1.14 & 98.43 \\
\hline HM-06 & 64.77 & 0.678 & 16.01 & 5.03 & 0.069 & 0.90 & 2.67 & 4.69 & 3.41 & 0.068 & 0.97 & 98.30 \\
\hline HM-07 & 66.13 & 0.613 & 15.92 & 4.11 & 0.049 & 0.78 & 2.53 & 4.87 & 3.44 & 0.066 & 1.15 & 98.51 \\
\hline HM-08 & 64.82 & 0.641 & 16.22 & 5.18 & 0.087 & 0.84 & 2.75 & 4.62 & 3.51 & 0.109 & 0.80 & 98.78 \\
\hline \multicolumn{13}{|c|}{ Outermost moraine } \\
\hline HМ-09 & 65.94 & 0.597 & 15.79 & 4.34 & 0.086 & 0.79 & 2.33 & 4.96 & 3.39 & 0.089 & 0.94 & 98.31 \\
\hline HM-10 & 64.13 & 0.684 & 16.50 & 5.21 & 0.086 & 0.69 & 2.59 & 4.68 & 3.58 & 0.065 & 1.46 & 98.22 \\
\hline HM-11 & 58.30 & 0.901 & 17.04 & 8.15 & 0.149 & 2.39 & 5.61 & 2.65 & 3.15 & 0.165 & 0.84 & 98.51 \\
\hline HM-12 & 66.39 & 0.602 & 15.75 & 4.03 & 0.085 & 0.72 & 2.25 & 4.91 & 3.46 & 0.080 & 1.08 & 98.28 \\
\hline \multicolumn{13}{|c|}{ North-Central Colorado } \\
\hline \multicolumn{13}{|c|}{ Middle Boulder Crk } \\
\hline MBC-01-1 & 74.96 & 0.088 & 14.41 & 1.60 & 0.014 & 0.30 & 3.31 & 0.51 & 4.58 & 0.012 & 0.25 & 100.03 \\
\hline MBC-01-2 & 72.22 & 0.403 & 14.06 & 2.82 & 0.030 & 0.48 & 1.03 & 5.34 & 3.03 & 0.044 & 0.53 & 99.99 \\
\hline \multicolumn{13}{|c|}{ North St. Vrain Crk } \\
\hline NSV-01-4 & 76.90 & 0.176 & 12.84 & 1.08 & 0.007 & 0.23 & 0.65 & 5.67 & 2.70 & 0.107 & 0.33 & 100.69 \\
\hline \multicolumn{13}{|l|}{ Roaring Fork Crk } \\
\hline RF-01-2 & 76.11 & 0.161 & 13.21 & 1.27 & 0.027 & 0.21 & 1.12 & 4.50 & 3.44 & 0.013 & 0.39 & 100.45 \\
\hline RF-01-3 & 76.19 & 0.174 & 13.38 & 1.32 & 0.029 & 0.21 & 1.02 & 4.50 & 3.53 & 0.024 & 0.37 & 100.75 \\
\hline RF-01-5 & 77.05 & 0.118 & 12.77 & 1.21 & 0.032 & 0.18 & 0.88 & 4.41 & 3.44 & 0.015 & 0.30 & 100.41 \\
\hline RF-01-6 & 75.21 & 0.214 & 13.13 & 1.99 & 0.035 & 0.30 & 1.03 & 4.50 & 3.43 & 0.018 & 0.50 & 100.36 \\
\hline RF-01-7 & 78.59 & 0.089 & 12.65 & 0.46 & 0.006 & 0.09 & 0.51 & 3.93 & 4.11 & 0.016 & 0.37 & 100.82 \\
\hline RF-01-9 & 74.25 & 0.294 & 13.76 & 2.14 & 0.035 & 0.27 & 1.43 & 3.47 & 4.05 & 0.017 & 0.33 & 100.05 \\
\hline
\end{tabular}


Table 6 (continued)

\begin{tabular}{|c|c|c|c|c|c|c|c|c|c|}
\hline Trace elements & $\begin{array}{l}\mathrm{Ba} \\
(\mathrm{ppm})\end{array}$ & $\begin{array}{l}\mathrm{Rb} \\
(\mathrm{ppm})\end{array}$ & $\begin{array}{l}\mathrm{Sr} \\
(\mathrm{ppm})\end{array}$ & $\begin{array}{l}\mathrm{Pb} \\
(\mathrm{ppm})\end{array}$ & $\begin{array}{l}\text { Th } \\
\text { (ppm) }\end{array}$ & $\begin{array}{l}\mathrm{U} \\
(\mathrm{ppm})\end{array}$ & $\begin{array}{l}\text { B } \\
(\mathrm{ppm})\end{array}$ & $\begin{array}{l}\mathrm{Gd} \\
(\mathrm{ppm})\end{array}$ & $\begin{array}{l}\mathrm{Cl} \\
(\mathrm{ppm})\end{array}$ \\
\hline \multicolumn{10}{|c|}{ Southwestern Colorado } \\
\hline \multicolumn{10}{|c|}{ Continental Reservoir } \\
\hline CR-01 & 975 & 102 & 515 & 11 & 11.0 & 3 & 8 & 5 & 134.0 \\
\hline CR-02 & 959 & 107 & 511 & 10 & 11.0 & 3 & 7 & 5 & 108.0 \\
\hline CR-03 & 1014 & 110 & 495 & 10 & 12.0 & 3 & 7 & 5 & 127.0 \\
\hline \multicolumn{10}{|c|}{ Hogback Mountain } \\
\hline \multicolumn{10}{|c|}{ Innermost moraine } \\
\hline HM-01 & 1106 & 131 & 483 & 13 & 15.0 & 3 & 12 & 4 & 84.9 \\
\hline HM-02 & 1121 & 143 & 380 & 13 & 15.0 & 4 & 14 & 4 & 40.2 \\
\hline HM-03 & 1082 & 150 & 329 & 14 & 18.0 & 4 & 13 & 5 & 68.2 \\
\hline HM-04 & 1154 & 136 & 431 & 14 & 15.0 & 3 & 14 & 4 & 102.0 \\
\hline \multicolumn{10}{|l|}{ Second moraine } \\
\hline HM-05 & 924 & 108 & 466 & 11 & 12.0 & 3 & 11 & 4 & 182.0 \\
\hline HM-06 & 1127 & 135 & 492 & 13 & 14.0 & 3 & 10 & 4 & 69.6 \\
\hline HM-07 & 1232 & 136 & 464 & 14 & 15.0 & 3 & 6 & 5 & 94.1 \\
\hline HM-08 & 1055 & 128 & 513 & 14 & 15.0 & 4 & 16 & 4 & 156.0 \\
\hline \multicolumn{10}{|c|}{ Outermost moraine } \\
\hline HM-09 & 1084 & 134 & 448 & 14 & 16.0 & 4 & 16 & 5 & 223.0 \\
\hline HM-10 & 1383 & 127 & 538 & 13 & 14.0 & 3 & 13 & 4 & 66.4 \\
\hline HM-11 & 802 & 60 & 632 & 6 & 4.0 & 1 & 6 & 4 & 295.0 \\
\hline HM-12 & 1117 & 135 & 433 & 15 & 15.0 & 4 & 14 & 5 & 87.6 \\
\hline \multicolumn{10}{|c|}{ North-Central Colorado } \\
\hline \multicolumn{10}{|c|}{ Middle Boulder Crk } \\
\hline MBC-01-1 & 56 & 25 & 343 & 13 & 12.6 & 11 & $<3$ & 2 & 101.0 \\
\hline MBC-01-2 & 1020 & 217 & 270 & 33 & 36.7 & 2 & $<3$ & 4 & 123.0 \\
\hline \multicolumn{10}{|c|}{ North St. Vrain Crk } \\
\hline NSV-01-4 & 318 & 244 & 68 & 32 & 6.6 & 1 & $<3$ & 2 & 48.8 \\
\hline \multicolumn{10}{|c|}{ Roaring Fork Crk } \\
\hline RF-01-2 & 826 & 167 & 161 & 21 & 4.4 & 3 & $<3$ & 1 & 89.0 \\
\hline RF-01-3 & 711 & 196 & 144 & 27 & 16.7 & 5 & $<3$ & 2 & 78.4 \\
\hline RF-01-5 & 560 & 210 & 112 & 24 & 2.8 & 3 & $<3$ & 2 & 64.3 \\
\hline RF-01-6 & 880 & 189 & 170 & 21 & 20.1 & 3 & $<3$ & 4 & 50.3 \\
\hline RF-01-7 & 646 & 134 & 139 & 14 & 11.4 & 6 & 3 & 1 & 52.3 \\
\hline RF-01-9 & 984 & 156 & 249 & 19 & 6 & 2 & $<3$ & 3 & 76.0 \\
\hline
\end{tabular}

$\mathrm{Fe}_{2} \mathrm{O}_{3}-\mathrm{T}$ is total iron expressed as $\mathrm{Fe}_{2} \mathrm{O}_{3}$.

LOI is loss on ignition.

To extract $\mathrm{Cl}$ for ${ }^{36} \mathrm{Cl}$ analyses, a 5:1 mixture of $\mathrm{HF}$ and $\mathrm{HNO}_{3}$ was added to Teflon bottles, containing 20-200 g (depending on initial $\mathrm{Cl}$ concentration) of leached sample. The bottles were allowed to sit on a warm hotplate for approximately 5 days to assure complete dissolution. After centrifugation, the supernatant was poured into Teflon beakers and $\mathrm{AgNO}_{3}$ was added to precipitate $\mathrm{AgCl}$. Sulfur removal ${ }^{36} \mathrm{~S}$ is an isobar of ${ }^{36} \mathrm{Cl}$ ) was accomplished by redissolving the $\mathrm{AgCl}$ with $\mathrm{NH}_{4} \mathrm{OH}$ and adding $\mathrm{Ba}\left(\mathrm{NO}_{3}\right)_{2}$ to precipitate $\mathrm{BaSO}_{4}$. The sample was centrifuged, the solution placed in a clean centrifuge tube, and $\mathrm{AgCl}$ was reprecipitated by adding $\mathrm{HNO}_{3}$. The samples were brought to neutral
$\mathrm{pH}$ by centrifuging and rinsing in $18 \mathrm{M} \Omega$ and dried on covered watch glasses in an oven at $<70{ }^{\circ} \mathrm{C},{ }^{36} \mathrm{Cl} /{ }^{37} \mathrm{Cl}$ and ${ }^{35} \mathrm{Cl} /{ }^{37} \mathrm{Cl}$ ratios of the purified $\mathrm{AgCl}$ precipitate were measured at the Center of Accelerator Mass Spectrometry facility at the Lawrence Berkeley National Laboratory under the supervision of R. Finkel. ${ }^{36} \mathrm{Cl}$ surface-exposure ages were calculated using the most recent version of the CHLOE program (Phillips and Plummer, 1996). Muon production in CHLOE is based on the work of Evans et al. (1998). In CHLOE the calculation of low-energy neutron absorption, the quantification of the flux distribution, and its dependence on chemical composition is based on work 
Table 7

Chlorine isotopic ratios for Colorado moraine-crest boulders

\begin{tabular}{|c|c|c|c|c|c|c|c|c|c|c|c|}
\hline \multicolumn{5}{|c|}{ North-central Colorado moraine-crest boulders } & \multirow{2}{*}{\multicolumn{3}{|c|}{${ }^{36} \mathrm{Cl} /{ }^{35} \mathrm{Cl}$ ratio }} & \multirow{2}{*}{\multicolumn{2}{|c|}{${ }^{35} \mathrm{Cl} /{ }^{37} \mathrm{Cl}$ ratio }} & \multirow{2}{*}{\multicolumn{2}{|c|}{$36 /$ totl $\mathrm{Cl}$}} \\
\hline Name & & S \# & S.F.O.M. & & & & & & & & \\
\hline & & & & & Ratio & \multicolumn{2}{|l|}{ \pm} & \multicolumn{4}{|l|}{ ratio } \\
\hline HM-01 & \multicolumn{2}{|c|}{ CL10805 } & 1.000 & & $5.962 \mathrm{E}-13$ & \multicolumn{2}{|l|}{$2.73 \mathrm{E}-14$} & \multicolumn{2}{|l|}{5.963} & \multicolumn{2}{|l|}{$5.11 \mathrm{E}-13$} \\
\hline HM-02 & \multicolumn{2}{|c|}{ CL10806 } & 1.000 & & $1.015 \mathrm{E}-12$ & \multicolumn{2}{|l|}{$2.30 \mathrm{E}-14$} & \multicolumn{2}{|l|}{6.891} & \multicolumn{2}{|l|}{$8.86 \mathrm{E}-13$} \\
\hline HM-03 & \multicolumn{2}{|c|}{ CL10807 } & 0.999 & & $6.968 \mathrm{E}-13$ & \multicolumn{2}{|l|}{$1.71 \mathrm{E}-14$} & \multicolumn{2}{|l|}{6.112} & \multicolumn{2}{|l|}{$5.99 \mathrm{E}-13$} \\
\hline HM-04 & \multicolumn{2}{|c|}{ CL10808 } & 0.999 & & $5.827 \mathrm{E}-13$ & \multicolumn{2}{|l|}{$1.42 \mathrm{E}-14$} & \multicolumn{2}{|l|}{6.280} & \multicolumn{2}{|l|}{$5.03 \mathrm{E}-13$} \\
\hline HM-05 & \multicolumn{2}{|c|}{ CL10809 } & 0.999 & & $3.896 \mathrm{E}-13$ & $1.26 \mathrm{E}-14$ & & 6.398 & & $3.37 \mathrm{E}-13$ & \\
\hline HM-06 & & 810 & 0.999 & & $6.474 \mathrm{E}-13$ & 2.04E-14 & & 6.634 & & $5.63 \mathrm{E}-13$ & \\
\hline HM-07 & & 811 & 0.999 & & $5.783 \mathrm{E}-13$ & $2.71 \mathrm{E}-14$ & & 5.689 & & $4.92 \mathrm{E}-13$ & \\
\hline HM-08 & & 812 & 0.996 & & 3.597E-13 & $1.03 \mathrm{E}-14$ & & 7.001 & & $3.15 \mathrm{E}-13$ & \\
\hline HM-09 & & 814 & 0.999 & & $3.221 \mathrm{E}-13$ & $7.99 \mathrm{E}-15$ & & 5.845 & & $2.75 \mathrm{E}-13$ & \\
\hline HM-10 & & 815 & 1.000 & & $6.834 \mathrm{E}-13$ & $1.79 \mathrm{E}-14$ & & 6.199 & & $5.88 \mathrm{E}-13$ & \\
\hline HM-11 & & 816 & 1.000 & & $7.070 \mathrm{E}-13$ & $1.66 \mathrm{E}-14$ & & 5.867 & & $6.04 \mathrm{E}-13$ & \\
\hline HM-12 & & 817 & 0.999 & & $6.059 \mathrm{E}-13$ & $1.23 \mathrm{E}-14$ & & 5.910 & & $5.18 \mathrm{E}-13$ & \\
\hline CR-01 & & 818 & 0.999 & & $6.549 \mathrm{E}-13$ & $1.82 \mathrm{E}-14$ & & 5.553 & & $5.55 \mathrm{E}-13$ & \\
\hline CR-02 & & 819 & 0.999 & & $6.869 \mathrm{E}-13$ & $1.62 \mathrm{E}-14$ & & 6.134 & & $5.91 \mathrm{E}-13$ & \\
\hline CR-03 & & 820 & 0.999 & & $6.655 \mathrm{E}-13$ & $1.57 \mathrm{E}-14$ & & 5.666 & & $5.66 \mathrm{E}-13$ & \\
\hline No blank cor & on was mac & ypical carrie & ckgrounds for nat & chlorine are & ${ }^{36} \mathrm{Cl} / \mathrm{Cl}=5 \times 10^{-15}$ & & & & & & \\
\hline $\begin{array}{l}\text { Southwestern } \\
\text { Name }\end{array}$ & $\begin{array}{c}\text { orado mora } \\
\text { CAMS \# }\end{array}$ & $\begin{array}{c}\text { crest boulde } \\
\text { S.F.O.M. }\end{array}$ & ${ }^{36} \mathrm{Cl}{ }^{37} \mathrm{Cl}$ Ratio & & Background & & Bkgrd-corr & cted & & ${ }^{35} \mathrm{Cl} /{ }^{37} \mathrm{Cl}$ ratio & \\
\hline & & & ratio & \pm & Ratio & \pm & Ratio & & \pm & Ratio & \pm \\
\hline MBC-01-1 & CL10160 & 0.999 & $2.598 \mathrm{E}-12$ & $6.11 \mathrm{E}-14$ & $8.21 \mathrm{E}-14$ & $1.23 \mathrm{E}-14$ & $2.518 \mathrm{E}-12$ & & $6.24 \mathrm{E}-14$ & 5.55 & 0.001 \\
\hline MBC-01-2 & CL10161 & 0.999 & $3.375 \mathrm{E}-12$ & $7.93 \mathrm{E}-14$ & $8.21 \mathrm{E}-14$ & $1.23 \mathrm{E}-14$ & $3.295 \mathrm{E}-12$ & & $8.03 \mathrm{E}-14$ & 5.77 & 0.004 \\
\hline NSV-01-4 & CL10167 & 0.999 & $5.842 \mathrm{E}-12$ & $1.12 \mathrm{E}-13$ & $8.21 \mathrm{E}-14$ & $1.23 \mathrm{E}-14$ & $5.764 \mathrm{E}-12$ & & $1.13 \mathrm{E}-13$ & 5.53 & 0.011 \\
\hline RF-01-2 & CL10169 & 0.999 & $4.821 \mathrm{E}-12$ & $1.12 \mathrm{E}-13$ & $8.21 \mathrm{E}-14$ & $1.23 \mathrm{E}-14$ & 4.742E-12 & & $1.13 \mathrm{E}-13$ & 5.89 & 0.004 \\
\hline RF-01-3 & CL10170 & 0.999 & $4.095 \mathrm{E}-12$ & $1.06 \mathrm{E}-13$ & $8.21 \mathrm{E}-14$ & $1.23 \mathrm{E}-14$ & $4.016 \mathrm{E}-12$ & & $1.06 \mathrm{E}-13$ & 4.72 & 0.003 \\
\hline RF-01-5 & CL10171 & 0.999 & $4.496 \mathrm{E}-12$ & $1.24 \mathrm{E}-13$ & $8.21 \mathrm{E}-14$ & $1.23 \mathrm{E}-14$ & $4.417 \mathrm{E}-12$ & & $1.25 \mathrm{E}-13$ & 5.86 & 0.009 \\
\hline RF-01-6 & CL10172 & 0.999 & $4.729 \mathrm{E}-12$ & $1.76 \mathrm{E}-13$ & $8.21 \mathrm{E}-14$ & $1.23 \mathrm{E}-14$ & $4.650 \mathrm{E}-12$ & & $1.76 \mathrm{E}-13$ & 5.49 & 0.010 \\
\hline RF-01-7 & CL10173 & 0.999 & $4.456 \mathrm{E}-12$ & $1.52 \mathrm{E}-13$ & $8.21 \mathrm{E}-14$ & $1.23 \mathrm{E}-14$ & $4.377 \mathrm{E}-12$ & & $1.53 \mathrm{E}-13$ & 5.50 & 0.020 \\
\hline RF-01-9 & CL10174 & 0.999 & $3.473 \mathrm{E}-12$ & $9.37 \mathrm{E}-14$ & $8.21 \mathrm{E}-14$ & $1.23 \mathrm{E}-14$ & $3.393 \mathrm{E}-12$ & & $9.45 \mathrm{E}-14$ & 5.82 & 0.010 \\
\hline $\mathrm{AgCl}$ Blank & CL10158 & 0.955 & $8.204 \mathrm{E}-14$ & $1.230 \mathrm{E}-14$ & & & $8.209 \mathrm{E}-14$ & & $1.230 \mathrm{E}-14$ & 3.16 & 0.003 \\
\hline
\end{tabular}

This is equivalent to $8 \times 10^{4}{ }^{36} \mathrm{Cl} / \mathrm{mg} \mathrm{Cl}$. Background-corrected ratios were calculated using the backgrounds indicated, based on measured blank $\mathrm{CL} 10158$. ${ }^{36} \mathrm{Cl} /{ }^{35} \mathrm{Cl}$ ratios were normalized to a standard (KNSTD) with a ${ }^{36} \mathrm{Cl} / \mathrm{Cl}$ ratio of $1.60 \times 10^{-12}$. Ratios were corrected for spurious counts resulting from sulfur contamination in the sample. A S.F.O.M. of 0.95 corresponds to a $5 \% \mathrm{~S}$ correction. The F.O.M. does not correct for the count rate suppression that can occur at high sulfur rates. ${ }^{35} \mathrm{Cl} /{ }^{37} \mathrm{Cl}$ ratios were measured relative to standards with an assumed natural ${ }^{35} \mathrm{Cl} /{ }^{37} \mathrm{Cl}$ ratio of 3.127 . 
discussed in Phillips et al. (2001). Spallation production constants for ${ }^{36} \mathrm{Cl}$ from $\mathrm{Ca}$ and $\mathrm{K}$ (66.8 and 154 atoms/ $\mathrm{g} / \mathrm{yr}$ ) derived by Phillips et al. (1996b, 2001) were used in all age calculations (see Table 7).

In addition, spallation production constants for ${ }^{36} \mathrm{Cl}$ from $\mathrm{Ca}$ and $\mathrm{K}$ (48.8 and 170 atoms/g/yr) derived by Stone et al. (1996) and Evans et al. (1997) were applied to calculation of the ${ }^{36} \mathrm{Cl}$ ages of three boulders from north-central Colorado. All ages were calculated using a bulk density of $2.7 \mathrm{~g} / \mathrm{cm}^{3}$ and a neutron attenuation coefficient of $170 \mathrm{~g} \mathrm{~cm}^{-2}$. The analytical error for ${ }^{36} \mathrm{Cl}$ ages is assumed to be $\leqslant 8 \%$ of the age (Phillips et al., 1997). The $8 \%$ value is probably an overestimate of analytical error in this study; therefore, we arbitrarily assigned an error of $5 \%$ to all ${ }^{36} \mathrm{Cl}$ age estimates.

\section{B.1.2. ${ }^{10}$ Be determinations}

Samples for ${ }^{10} \mathrm{Be}$ measurements were sawn to a uniform thickness $(4-5 \mathrm{~cm})$, crushed, and quartz concentrated from the 250 to $500 \mu \mathrm{m}$ fraction using magnetic and heavy-liquid techniques. All samples were treated in $>1 \mathrm{M} \mathrm{HCl}$ on shaker table for $24 \mathrm{~h}$ to remove carbonates and oxide coatings on quartz. Samples were then rinsed in de-ionized water and air-dried. Pure quartz separates were prepared by etching concentrates in a solution of $2 \% \mathrm{HF}$ and $1 \% \mathrm{HNO}_{3}$ over a 5 -day period in an ultrasonic bath. The concentrate-tosolution ratio was $7 \mathrm{~g} / \mathrm{L}$. Acids were changed daily. This process yielded nearly pure quartz with trace amounts of a metallic sulfide that were removed by hand.

From 20 to $30 \mathrm{~g}$ of quartz separate were dissolved in $\mathrm{HF}$ and spiked with $300 \mu \mathrm{g}$ of Be carrier (Spectrosol Be standard $1000 \mathrm{mg} / \mathrm{L}$ with a ${ }^{10} \mathrm{Be} /{ }^{9} \mathrm{Be}$ ratio of $\left.2.3 \times 10^{-14}\right)$. A procedural blank consisting of pure carrier was run at the same time as the samples. Be was separated from other species (chiefly $\mathrm{Fe}, \mathrm{Al}$, and $\mathrm{Ti}$ ) using ion-exchange columns and precipitation of $\mathrm{Be}(\mathrm{OH})_{2}$ at a $\mathrm{pH}$ of 8.5 to 9.0. The hydroxide was converted to $\mathrm{BeO}$ by firing in a quartz crucible over an open flame until incandescent. Powdered Ag was mixed with $\mathrm{BeO}$ in the crucible and pressed into a cathode for analysis by AMS.

AMS analyses were conducted at the PSI/ ETH AMS facility with a terminal voltage of $5.8 \mathrm{MV}$. The reported isotope ratios were normalized to Be standard S555 with a nominal value of ${ }^{10} \mathrm{Be} / \mathrm{Be}=95.5 \times 10^{-12}$. All ages were corrected for the carrier blank and for sample thickness using a bulk density of $2.7 \mathrm{~g} / \mathrm{cm}^{3}$ and a neutron attenuation coefficient of $170 \mathrm{~g} / \mathrm{cm}^{2}$.

Exposure ages were computed using a ${ }^{10} \mathrm{Be}$ production rate of $5.4 \mathrm{atom} / \mathrm{g} / \mathrm{yr}$ at sea level and high latitude (SLHL). This production rate is an average of the Köfels calibration site in Austria (Kubik and Ivy-Ochs, 2004) and the Wind River site in Wyoming (Klein and Gosse, 2002). Production rates were scaled from SLHL to our Colorado sites using the procedures of Stone (2000), with the fraction of production by neutron spallation set at 0.974 . Errors $(1 \sigma)$ are analytical (AMS and target chemistry) uncertainties plus the error reported for the SLHL production rate. No correction was made of dipole-induced variability of production rates. Geographic latitude was used in scaling of Colorado production rates in that production rates at midlatitudes are not thought to be sensitive to geomagnetic field strength (Cerling and Craig, 1994; Phillips et al., 1996b).

Table 8

Snow course values for Colorado and Wyoming (Pinedale) sites

\begin{tabular}{lllll}
\hline Moraine site & N. St. Vrain Crk & Mid. Boulder Crk & Roaring Fk & Continental Res \\
\hline Snow course site & Copeland Lk & Baltimore & Willow Crk & Porcupine \\
Snow course elev $(\mathrm{m})$ & 2620 & 2680 & 2910 & 3130 \\
Record length $(\mathrm{yr})$ & $38-52$ & 42 & $61-63$ & $49-52$ \\
Ave snow density $\left(\mathrm{g} / \mathrm{cm}^{3}\right)$ & 0.26 & 0.26 & 0.28 & 0.25 \\
$\quad$ Snow depth $(\mathrm{cm})$ & 36 & 51 & 84 & 76 \\
$\quad$ Feb & 46 & 58 & 104 & 86 \\
$\quad$ Mar & 41 & 64 & 114 & 94 \\
Apr & 20 & 38 & 86 & 56 \\
May & Hogback Mtn & Pinedale & Pinedale \\
\hline Moraine site & Santa Maria & Middle Fk & Pinedale & T-Cross Ranch \\
\hline Snow course site & 2930 & 2262 & Sheridan, R.S. & 2408 \\
Snow course elev $(\mathrm{m})$ & 63 & 35 & 2374 & 62 \\
Record length $(\mathrm{yr})$ & 0.24 & 0.27 & $45-51$ & 0.27 \\
Ave snow density $\left(\mathrm{g} / \mathrm{cm}^{3}\right)$ & 43 & 43 & 61 & 58 \\
Snow depth $(\mathrm{cm})$ & 48 & 53 & 66 & 66 \\
$\quad$ Feb & 41 & 66 & 69 & 30 \\
Mar & 8 & 43 & 30 & 30 \\
Apr & & & \\
May & & & & 56 \\
\hline
\end{tabular}




\section{Appendix C}

For snow course values for Colorado and Wyoming sites see Table 8 .

\section{References}

Atwood, W.A., Mather, K.F., 1932. Physiography and quaternary geology of the San Juan Mountains, Colorado. US Geological Survey Professional Paper 166.

Benedict, J.B., 1993. Influence of snow upon rates of granodiorites weathering, Colorado Front Range, USA. Boreas 22, 87-92.

Benson, L., Lund, S., Negrini, R., Linsley, B., Zic, M., 2003. Response of North American Great Basin lakes to Dansgaard-Oeschger oscillations. Quaternary Science Reviews 22, 2239-2251.

Benson, L., Madole, R., Phillips, W., Landis, G., Thomas, T., Kubik, P., 2004. The probable importance of snow and sediment shielding on cosmogenic ages on north-central Colorado Pinedale and pre-Pinedale moraines. Quaternary Science Reviews 23, 193-206.

Blackwelder, E., 1915. Post-Cretaceous history of the mountains of central Wyoming, Part III. Journal of Geology 23, 307-340.

Caine, N., 1979. Rock weathering rates at the soil surface in an alpine environment. Catena 6, 131-144.

Carrara, P.E., Mode, W.N., Rubin, M., Robinson, S.W., 1984. Deglaciation and postglacial timberline in the San Juan Mountains, Colorado. Quaternary Research 21, 42-55.

Cerling, T.E., Craig, H., 1994. Cosmogenic ${ }^{3} \mathrm{He}$ production rates from $39^{\circ}$ to $46^{\circ} \mathrm{N}$ latitude, western USA and France. Geochimica et Cosmochimica Acta 58, 249-255.

Clark, P.U., Bartlein, P.J., 1995. Correlation of late Pleistocene glaciation in the western United States with North Atlantic Heinrich events. Geology 23, 483-486.

Dunne, J., Elmore, D., Muzikar, P., 1999. Scaling factors for the rates of production of cosmogenic nuclides for geometric shielding and attenuation at depth on sloped surfaces. Geomorphology 27, 3-11.

Elias, S.A., Carrara, P.E., Toolin, L.J., Jull, A.J.T., 1991. Revised age of deglaciation of Lake Emma based on new radiocarbon and macrofossil analyses. Quaternary Research 36, 307-321.

Evans, J.M., Stone, J.O.H., Fifield, L.K., Cresswell, R.G., 1997. Cosmogenic chlorine-36 production in K-feldspar. Nuclear Instruments and Methods in Physics B 123, 334-340.

Evans, J.M., Stone, J.O.H., Fifield, L.K., Allan, G.L., Cresswell, R.G., 1998. Cosmogenic chlorine-36 production in calcite by muons. Geochimica et Cosmochimica Acta 62, 433-454.

Gosse, J.C., 2004. The contribution of cosmogenic nuclides to unraveling alpine paleo-glacier histories. In: Huber, U., Bugmann, H., Reasoner, M. (Eds.), Global Change and Mountain Regions: A State of Knowledge Overview, Kluwer Scientific Publishers, Zurich, Switzerland.

Gosse, J.C., Phillips, F.M., 2001. Terrestrial in situ cosmogenic nuclides: theory and application. Quaternary Science Reviews 20, $1475-1560$.

Gosse, J.C., Klein, J., Evenson, E.B., Lawn, B., Middleton, R., 1995. Beryllium-10 dating of the duration and retreat of the last Pinedale glacial sequence. Science 268, 1329-1333.

Gosse, J.C., Evenson, E.B., Klein, J., Sorenson, C., 2003. Cosmogenic nuclide glacial geochronology in the Wind River Range, Wyoming. In: Easterbrook, D.J. (Ed.), Quaternary Geology of the United States, INQUA 2003 Field Trip Guide Volume. Desert Research Institute, Reno, Nevada, pp. 49-56.
Hallet, B., Putkonen, J., 1994. Surface dating of dynamic landforms: young boulders on aging moraines. Science $265,937-940$.

Hughen, K., Lehman, S., Southon, J., Overpeck, J., Marchal, O., Herring, C., Turnbull, J., 2004. ${ }^{14} \mathrm{C}$ activity and global carbon cycle changes over the past 50,000 years. Science 303, 202-206.

Klein, J., Gosse, J.C., 2002. Production rates of ${ }^{10} \mathrm{Be}$ and ${ }^{26} \mathrm{Al}$ in midlatitudes and high altitudes. Goldschmidt Conference Abstracts, p. 403

Kubik, P.W., Ivy-Ochs, S., 2004. A re-evaluation of the $0-10 \mathrm{ka}{ }^{10} \mathrm{Be}$ production rate for exposure dating obtained from the Köfels (Austria) landslide. Nuclear Instruments and Methods B 223-224, 618-622.

Licciardi, J.M., Clark, P.U., Brook, E.J., Pierce, K.L., Kurz, M.D., Elmore, D., Sharma, P., 2001. Cosmogenic ${ }^{3} \mathrm{He}$ and ${ }^{10} \mathrm{Be}$ chronologies of the late Pinedale northern Yellowstone ice cap, Montana, USA. Geology 29, 1095-1098.

Licciardi, J.M., Clark, P.U., Brook, E.J., Elmore, D., Sharma, P., 2004. Variable responses of western US glaciers during the last deglaciation. Geology 32, 81-84.

Masarik, J., Wieler, R., 2003. Production rates of cosmogenic nuclides in boulders. Earth and Planetary Science Letters 216, 201-208.

Masarik, J., Kollar, D., Vanya, S., 2000. Numerical simulation of in situ production of cosmogenic nuclides: effects of irradiation geometry. Nuclear Instrumental Methods B 172, 786-789.

McCabe, G.J., Fountain, A.G., Dyurgerov, M., 2000. Variability in winter mass balance of Northern Hemisphere glaciers and relations with atmospheric circulation. Arctic, Antarctic, and Alpine Research 32, 64-72.

Phillips, F.M., Plummer, M.A., 1996. CHLOE: A program for interpreting in-situ cosmogenic nuclide data for surface exposure and erosion studies. Radiocarbon 38, 98.

Phillips, F.M., Zreda, M.G., Benson, L.V., Plummer, M.A., Elmore, D., Sharma, P., 1996a. Chronology for fluctuations in Late Pleistocene Sierra Nevada glaciers and lakes. Science 274, 749-751.

Phillips, F.M., Zreda, M.G., Elmore, D., Sharma, P., 1996b. A reevaluation of cosmogenic ${ }^{36} \mathrm{Cl}$ production rates in terrestrial rocks. Geophysical Research Letters 23, 949-952.

Phillips, F.M., Zreda, M.G., Gosse, J.C., Klein, J., Evenson, E.B., Hall, R.D., Chadwick, O.A., Sharma, P., 1997. Cosmogenic ${ }^{36} \mathrm{Cl}$ and ${ }^{10} \mathrm{Be}$ ages of Quaternary glacial and fluvial deposits of the Wind River Range, Wyoming. Geological Society of America Bulletin 109, 1453-1463.

Phillips, F.M., Stone, W.D., Fabryka-Martin, J., 2001. An improved approach to calculating low-energy cosmic ray neutron fluxes near the land/atmosphere interface. Chemical Geology 175, 689-701.

Richmond, G.M., 1964. Three pre-Bull Lake Tills in the Wind River Mountains, Wyoming; A reinterpretation. US Geological Survey Professional Paper 501-D, D104-D109.

Richmond, G.M., 1973. Geologic map of the Fremont Lake South quadrangle, Sublette County, Wyoming. US Geological Survey Geologic quadrangle map GQ-1138, scale 1:24000.

Richmond, G.M., 1987. Type Pinedale Till in the Fremont Lake area, Wind River Range, Wyoming, Geological Society of America Centennial Field Guide-Rocky Mountain Section, pp. 201-204.

Stone, J., 2000. Air pressure and cosmogenic isotope production. Journal of Geophysical Research 105, 23753-23759.

Stone, J., Allan, G.L., Fifield, L.K., Cresswell, 1996. Cosmogenic chlorine-36 from calcium spallation. Geochimica et Cosmochimica Acta $60,692-769$.

Zimmerman, S.G., Evenson, E.B., Gosse, J.C., Erskine, C.P., 1994. Extensivie boulder erosion resulting from range fire on the typePinedale moraines, Fremont Lake, Wyoming. Quaternary Research 42, 255-265. 